\title{
U.S. Regional Differences in Physical Distancing: Evaluating Racial and Socioeconomic Divides During the COVID-19 Pandemic
}

Emma Zang ${ }^{1 *}$, Jessica West $^{2}$, Nathan $\mathrm{Kim}^{1}{ }^{1}$, Christina Pao. ${ }^{3}$

\author{
Authors' affiliations: \\ ${ }^{1}$ Department of Sociology, Yale University, New Haven, CT 06520 \\ ${ }^{2}$ Department of Sociology, Duke University, Durham, NC 27708 \\ ${ }^{3}$ Department of Sociology, University of Oxford, Oxford OX1 2JD, United Kingdom
}

Corresponding author: * Emma Zang, Ph.D., Department of Sociology, Yale University, New Haven, CT 06511. Phone: +1 (919) 536-9621. Email: emma.zang@yale.edu.

\section{Conflict of Interest:}

None.

\section{Funding:}

This work was supported by the Claude D. Pepper Older Americans Independence Center at Yale School of Medicine, funded by National Institute on Aging (P30AG021342). 


\author{
U.S. Regional Differences in Physical Distancing: \\ Evaluating Racial and Socioeconomic Divides During the COVID-19 Pandemic
}

\begin{abstract}
Health varies by U.S. region of residence. Despite regional heterogeneity in the outbreak of COVID-19, regional differences in physical distancing behaviors over time are relatively unknown. This study examines regional variation in physical distancing trends during the COVID-19 pandemic and investigates variation by race and socioeconomic status (SES) within regions.

Data from the 2015-2019 five-year American Community Survey were matched with anonymized location pings data from over 20 million mobile devices (SafeGraph, Inc.) at the Census block group level. We visually present trends in the stay-at-home proportion by Census region, race, and SES throughout 2020 and conduct regression analyses to statistically examine these patterns.

From March to December, the stay-at-home proportion was highest in the Northeast $(0.25$ in March to 0.35 in December) and lowest in the South (0.24 to 0.30). Across all regions, the stayat-home proportion was higher in block groups with a higher percentage of Blacks, as Blacks disproportionately live in urban areas where stay-at-home rates were higher $(0.009$ [CI: 0.008, 0.009]). In the South, West, and Midwest, higher-SES block groups stayed home at the lowest rates pre-pandemic; however, this trend reversed throughout March before converging in the months following. In the Northeast, lower-SES block groups stayed home at comparable rates to higher-SES block groups during the height of the pandemic but diverged in the months following.
\end{abstract}

Differences in physical distancing behaviors exist across U.S. regions, with a pronounced Southern and rural disadvantage. Results can be used to guide reopening and COVID-19 mitigation plans. 


\section{Introduction}

In the first half of 2020 , the U.S. comprised $4 \%$ of the world's population but $1 / 4$ of the confirmed coronavirus disease 2019 (COVID-19) cases and deaths (1). By April 26, 2021, the U.S. had recorded over 31 million cases of and 569,272 deaths due to COVID-19 (2). In an effort to contain the spread of the virus, reducing contact between infected and susceptible individuals became the key strategy to prevent disease transmission $(3,4)$. As such, in March 2020, public health and government officials imposed restrictions on domestic and international travel at the federal level, and began recommending physical distancing behaviors at the state level (e.g., maintaining six feet of distance, avoiding group gatherings, stay-at-home-orders, and the closure of non-essential businesses and schools $(5,6)$ ) to mitigate the spread of COVID-19 (note that we use "physical distancing" rather than "social distancing" to emphasize the importance of preserving social—while reducing physical—interactions (5)).

While the virus has reached most areas of the U.S., there is evidence of regional variation with the country. While the pandemic initially struck the West and the Northeast hardest, COVID-19 cases later rose in the Midwest and the South (2), resulting in regional differences in COVID-19 outcomes such as cases and deaths $(7,8)$. For example, research has revealed regional differences by the percentage of counties that met criteria for being a "hotspot." Specifically, in March-April, counties in the Northeast Census region met hotspot criteria more often than all other regions; however, by June-July, counties in the South and West Census regions were proportionally meeting hotspot criteria more than the Northeast and Midwest (9). These differences may be due to regional variation in factors that influence COVID-19 risks, including various individual (e.g., age, pre-existing health conditions), household (e.g., poverty, household size), and community (e.g., presence of group quarters such as correctional facilities 
or nursing homes) factors (10). This is consistent with a long line of research on regional variation in health and mortality (11-16).

Despite apparent regional differences in COVID-19 outcomes, there has been little focus on how physical distancing behavior varies by region, which is an important omission because physical distancing trends are predictive of later COVID-19 outcomes (3). There are many reasons to believe that physical distancing may be structurally constrained by region. For example, compared to other regions, the South had a higher prevalence of poor health and preexisting chronic conditions $(16,17)$, which might have increased medical facility visitation and limited physical distancing ability. Moreover, the prevalence of physical activities was particularly low in the South (17), and places with more health-protective behaviors prior to the pandemic (e.g., greater physical activity) exhibited a greater reduction in movement outside of the home (18). The South also has higher poverty rates compared to other regions (19), and socioeconomic status (SES) is positively associated with physical distancing (20). Understanding regional differences in physical distancing trends may highlight particular regions where COVID-19 mitigation policies and outreach should be targeted.

Additionally, region may shape SES and racial differences in physical distancing, and therefore it is important to examine these differences within each region. Physical distancing necessitates the ability to work from home, distance while working from home, take (un)paid time off, etc. $(21,22)$. While physical distancing was generally high following state emergency guidelines, the intensity of distancing correlated dramatically with income (20). Moreover, racial/ethnic minority groups disproportionately work in low-wage or essential work settings (23, 24) where COVID-19 exposure risk is high $(25,26)$. Even when racial/ethnic minorities can remain home, they overwhelmingly live in places that put them at higher risk for COVID-19 (21, 
27). Because delayed testing and lack of accessible health care, public health resources, and paid leave is particularly severe in the South, physical distancing patterns may be particularly unequal across SES and racial groups in the South (28).

One way to examine regional differences in physical distancing trends is via aggregated mobility data from mobile devices. The pandemic has accelerated the use of such data for various purposes including mapping population movement, developing models of disease transmission, and informing resource allocation $(29,30)$. Such research has shown that physical distancing and stay-at-home orders have contributed to reducing the growth rate of COVID-19 $(3,31)$ and that measures of physical distancing (e.g., maximum travel distance, stay-at-home time, decreases in physical movement) are associated with a reduction in COVID-19 case rates $(32,33)$. However, there is notable variation in adherence to physical distancing recommendations. Several studies have shown that high SES individuals were more likely to engage in physical distancing behaviors compared to low SES individuals $(3,20,34,35)$. County-level shares of racial/ethnic minorities and rurality have also been associated with reduced physical distancing, but these trends vary across the pandemic (34). There is also evidence that in states where the confirmed COVID-19 cases were increasing faster, people generally reduced their mobility more quickly $(32,36)$. Overall, there is a growing literature tracking mobility changes in the U.S. over the course of the pandemic.

The current study aims to contribute to this nascent literature by using nationally representative data at the Census block group level to, 1) show regional trends in physical distancing practices over the course of the pandemic, and 2) examine differences within each region by race and SES (income, education, occupation) using visual tools and regression analyses. As such, the purpose of the study is to present descriptive patterns of regional variation 
in physical distancing rather than causal determinants of these behaviors. Findings from this study may help policymakers determine which regions are most affected and which communities might be most impacted within these regions.

\section{Materials and Methods}

We use anonymized location data from SafeGraph, Inc. which were collected from a representative sample (37) of over 20 million cell phones and recorded daily at the Census block group level from January $1^{\text {st }}, 2019$ to December $31^{\text {st }}, 2020$ (see a map in the appendix for the completeness of the data at the national level). A Census block group is a geographical unit between the size of a Census tract and a Census block and typically contains between 600 to 3,000 people. Compared to larger geographic divisions (e.g., counties), the block group aligns closely with neighborhood boundaries and is useful for studying segregated areas like cities.

For our main analyses, we represent the extent of physical distancing with a seven-day rolling average of the proportion staying completely at home. "Home" is defined as the geohash7 , or approximately a 153 -meter by 153 -meter area, that serves as the most common nighttime location for each device. This measure has been used to capture physical distancing in other studies $(36,38)$. We also study various alternative measures (39) and results are consistent (see Appendix A1 and regional-distancing.info for an interactive tool to explore these metrics over time at the state level).

Next, we match stay-at-home rates with demographic information on urbanicity, age, race, and SES from the 2015-2019 five-year American Community Survey (ACS) at the Census block group level. From the ACS, we obtain urbanicity (urban vs. rural); the proportion of residents over age 65 ; the proportion of the population identifying as Black of any ethnicity; 
median household income; proportion of Bachelor's degree holders; and proportion of frontline workers (see Appendix A2 for definition of frontline workers and robustness checks).

As there is no consensus about which geographic level (region, division, etc.) to use to track health differences (40), we use Census region: Northeast, Midwest, South, and West (41). Regional analyses may mask heterogeneity across counties/states; however, regional analyses minimize migration effects (people are half as likely to move between regions as between states in any given year (42)) and issues related to classifying people who live/work in different counties/states.

\section{Statistical methods}

We present trends in the stay-at-home proportion by Census region and conduct linear regression models at the Census block group level to examine regional differences over time. Specifically, we regress the stay-at-home proportions across Census regions, the linear and quadratic forms of the number of days since January $1^{\text {st }}, 2020$, and a "time period" variable as well as its interactions with Census regions. To account for variations from the nationwide surge in stay-at-home rates throughout April, we defined these time periods as before April $1^{\text {st }}$, April $1^{\text {st }}-$ May $1^{\text {st }}$, and after May $1^{\text {st }}$. In addition to the baseline model without controls, to examine whether the observed physical distancing patterns are mainly driven by age and racial compositions, SES, and urbanicity, we control for the following covariates in the model: urbanicity, proportion of residents over age 65 , the proportion of the population identifying as Black of any ethnicity, median household income, proportion of Bachelor's degree holders, and proportion of frontline workers.

We then plot the physical distancing patterns by race and SES for each region. To represent time, stay-at-home rates, and demographic measures together on one plot per 
demographic variable, we divided the nation into deciles for each measure. Because there are many block groups with 0 Black residents, we grouped all block groups with 0 Black residents into a " 0 " decile, resulting in the removal of the $1^{\text {st }}$ and $2^{\text {nd }}$ decile and a considerably smaller sample size in the $3^{\text {rd }}$ decile. We investigate all of these SES trends within each region to investigate how these social conditions' relationship with physical distancing varies by geography. For the dimension of race, considering Black Americans disproportionately reside in urban areas, Figure 3 divides block groups across deciles of proportion Black and the urban-rural status of the county (based on the U.S. Census Bureau's 2010 Urban-Rural Classification System (43)). We additionally conduct linear regression models for each Census region to examine whether the differences along the racial and SES lines are statistically meaningful. For each Census region, we use race/SES, time period, and the interaction terms between race/SES and time period to predict physical distancing, after controlling for linear and quadratic forms of days since January $1^{\text {st }}, 2020$. Besides our focuses on race and SES, we present additional results by proportions of residents over age 65 in Appendix Table 5.

\section{Results}

Figure 1 presents stay-at-home patterns by Census region. For contextualization purposes, we show the $10^{\text {th }}$ and $40^{\text {th }}$ state-level stay-at-home orders, issued in Michigan (March $\left.24^{\text {th }}\right)$ and South Carolina (April $\left.7^{\text {th }}\right)$. Stay-at-home order information was taken from Boston University’s COVID-19 U.S. State Policy Database (44).

Before March, the stay-at-home proportion was similar across regions, with $24-25 \%$ of the population staying home on any given day. After the enactment of stay-at-home orders and school closures, nearly all regions experienced a sharp increase in the stay-at-home proportion. The largest increase occurred in Northeast block groups: the seven-day rolling average of the 
stay-at-home proportion increased from 0.25 on March $1^{\text {st }}$ to 0.46 near the height on April $1^{\text {st }}$ before falling to 0.35 on December $31^{\text {st }}$. In the South, this trend repeats at considerably lower rates: the rolling stay-at-home proportion rose from $0.24\left(\right.$ March $1^{\text {st }}$ ) to 0.37 (April $1^{\text {st }}$ ), then drops to 0.3 (December $31^{\text {st }}$ ). The West and Midwest fall in between, with the proportion on these dates for the Midwest being $0.25,0.41$, and 0.32 compared to $0.25,0.43$, and 0.35 for the West. These downward arching trends over time are notable given the at best, stagnating, and at worst, intensifying, case rates.

\section{[Figure 1]}

Table 1 presents OLS model results, which confirm our observations in Figure 1. All variables are predictive of stay-at-home rates with $P$-values less than 0.001 . The left panel shows the results without race, SES, and urban status controls. There was a surge in physical distancing during April; nonetheless, this increase declined after April, though physical distancing rates were still higher than pre-pandemic rates. Before April, physical distancing rates were highest in the Northeast, followed by the West and Midwest, and were the lowest in the South. The interactions between region and the time periods show that regional differences expanded during the surge in physical distancing from April $1^{\text {st }}$ to $30^{\text {th }}$ and contracted afterwards: in the Northeast, the difference in stay-at-home rates before April 1st and between April 1st and $30^{\text {th }}$ is 0.054 [CI: 0.054, 0.055] higher than the difference in stay-at-home-rates in the Midwest, suggesting that the baseline differences in physical distancing between the Midwest and the Northeast were made even greater during the peak of physical distancing.

Results in the rightmost panel control for age, race, SES, and urban status. Proportion of college degree holders, proportion Black, proportion of frontline workers, proportion of residents over age 65, and urbanicity positively predict physical distancing, whereas median household 
income negatively predicts physical distancing before April. The coefficients for period, region, as well as the interaction terms remain largely unchanged, indicating that adjusting for these variables does not change the general patterns of regional differences observed in Figure 1. Supplementary results (Appendix A3) by Census division and state further show considerable variations within and across Census divisions.

\section{[Table 1]}

Figure 2 presents stay-at-home patterns by the proportion of Black residents for each Census region. Within each region, block groups with the highest proportion of Black residents had the highest stay-at-home rates throughout the pandemic, albeit to varying extents. Figure 2 also reveals that nationwide differences between the block groups with the most and least Black residents vary across regions. The difference in the seven-day rolling stay-at-home rate for block groups with the highest and lowest proportion Black residents in the Northeast is roughly 0.05 on April $1^{\text {st }}, 0.08$ on August $1^{\text {st }}$, and 0.05 in December. In the South, these differences are smaller: $0.01,0.06$, and 0.03 , respectively. Results from regression models reinforce these trends, with the coefficients for proportion Black residents being positive across regions before April (Appendix Table A1). The negative interaction terms between proportion Black residents and the time period of April across regions indicate that differences in physical distancing across a block's proportion of Black residents narrowed during April. These differences further narrowed after April in the Midwest and South but increased in the Northeast and West. All aforementioned results are statistically significant with P-values smaller than 0.001 .

[Figure 2]

Our finding that block groups with higher proportions of Blacks tended to stay home at higher rates appears to contradict some reports on large cities (e.g., Detroit $(45,46))$. Further 
investigation (Figure 3) explains these inconsistent findings. When looking at rural-urban divisions separately, block groups with the highest proportion of Black residents appear to stay home the least during the peak of the pandemic. However, urban residents generally stayed at home at a much higher rate than rural residents (Figure 3). Blacks disproportionally reside in cities, and therefore, when looking at patterns nationwide (see Figure 2), block groups with the highest proportion of Black residents stayed at home at the highest rates.

[Figure 3]

To address SES differences, we show Census region physical distancing trends by occupation (Figure 4), educational attainment (Figure 5), and median household income (Figure 6). Patterns are similar across the three variables. Pre-pandemic, higher SES block groups (e.g., lowest proportion of frontline workers, highest proportion of Bachelor's-degree-holders, or highest proportion in the top decile of median household income) stayed home at the lowest rates; however, this trend reversed throughout March in the Midwest, South, and West before converging in months following. In the Northeast, however, lower SES block groups stayed home at comparable rates to higher SES block groups during the height of the pandemic but diverged in the months following. For example, while the difference in stay-at-home rates between block groups with the least and most frontline workers in the South is 0.01 on April $1^{\text {st }}$, this difference is -0.05 for the Northeast. Similarly, in the South, the difference in stay-at-home rates between the most- and least-educated block groups on April $1^{\text {st }}$ is 0.11 ; in the Northeast, the difference is considerably smaller at about 0.02. Regression results (Appendix Tables A2-A4) confirm these results (all results statistically significant at $\mathrm{p}<0.001$ ).

[Figures 4, 5, 6]

\section{Discussion}


Decades of research has documented regional variation in health outcomes, life expectancy, and mortality (11-16). Recent research indicates that regional variation has remained a crucial part of understanding health-related patterns in the U.S. during the COVID-19 pandemic. For instance, U.S. Census region was associated increases in psychological stress during the pandemic (47), interest and adoption in telehealth (48), and COVID-19 preparedness in home health agencies (49). Research that disaggregated COVID-19 outcomes by region was also crucial in confirming the nationwide pattern of the changing age distribution (i.e., the shift in highest incidence of cases from older adults to younger adults) over the course of the pandemic (50). However, few studies have examined regional differences in physical distancing behaviors which is problematic because physical distancing trends are predictive of later COVID-19 outcomes $(3,4)$ and access to physical distancing may be structurally constrained by U.S. region. At the county level, there is some evidence that counties with more health-protective behaviors prior to the pandemic (e.g., less obesity, greater physical activity) exhibited a greater reduction in movement outside of the home compared to counties with fewer health-protective behaviors (18). Moreover, evidence suggests that poor housing conditions (e.g., overcrowding) were associated with higher COVID-19 incidence and mortality rates during March and April 2020, suggesting that inability to distance from others may explain the increased incidence of COVID-19 (8). These studies provide preliminary evidence that understanding regional differences in physical distancing trends may highlight particular regions where COVID-19 mitigation policies and outreach should be targeted and when such policies are particularly urgent.

Building on this nascent literature, the current study examined physical distancing trends across U.S. regions, and racial and SES differences within region. First, physical distancing 
practices vary widely across U.S. regions (see Appendix Figures A2 and A3), with a particular disadvantage for the South. Southerners tend to lack access to health insurance $(51,52)$, which is likely exacerbated by pandemic-related unemployment (53). Moreover, poverty is persistently higher in the South (19), further restricting access to the resources needed to live a healthy life. Inability to engage in physical distancing behaviors puts Southerners at greater risk for negative COVID-19 outcomes. Notably, each region stayed home at the same times even though the pandemic struck some regions much later than others. However, while all regions stayed home at the highest rates in April, the South had the lowest physical distancing rates of the four regions. For a few months (July-October), the Midwest replaced the South with the lowest physical distancing rates. Over the entire time period, our study shows that the Southern disadvantage in health and mortality $(13,16)$ (and, for a few months, a Midwestern disadvantage (51)) extends to physical distancing behaviors. As such, services, interventions, social safety nets, and public expenditures may be particularly necessary to help people living in the South survive the pandemic.

In addition to a Southern disadvantage, our results add to previous literature documenting a rural disadvantage. Rural America is challenged by lack of access to health care, poor health behaviors, poverty, and educational underachievement—social factors that are additionally challenging during the COVID-19 pandemic (54). We find that rural residents are less likely to stay home compared to urban residents but note that existing media and reports tend to focus on physical distancing in cities. Thus, emphasis on physical distancing behaviors may be particularly important within rural areas.

Second, the overrepresentation of Black individuals in the number of cases, hospitalizations, and deaths associated with COVID-19 (22) is not simply driven by a difference 
in physical distancing patterns. In fact, nationwide, block groups with more Black residents generally stayed-at-home more than block groups with fewer Black residents. Existing media outlets and reports tended to focus only on cities, and therefore claimed that Blacks were disproportionally affected due to physical distancing patterns $(45,46)$. In contrast, our results by rural-urban status and race highlight the need to study the interaction between different social conditions in creating observed stay-at-home patterns.

Third, physical distancing patterns vary across SES: physical distancing is higher among block groups that are wealthier, more educated, or contain the lowest proportion of frontline workers. However, wealthier individuals became more mobile at the onset of summer (June/July), likely to travel to summer destinations (55). This socioeconomic disadvantage intersects with racial disadvantage, as demonstrated by other research that reveals higher infection rates among disadvantaged racial and socioeconomic groups due to mobility differences: individuals from disadvantaged groups are unable stay at home and the points of interest (e.g., grocery stores) that they visit are more crowded and thus associated with higher COVID-19 risk (56). Our results confirm that SES is an important factor for COVID-19 exposure and mitigation strategies and extends research examining physical distancing and income (20) by also including measures of education and occupation.

Together, our findings reflect decades of research showing that racial and socioeconomic differences are social conditions that contribute to health differences $(57,58)$. As a result of persisting social inequities, individuals and groups that were more likely to experience health differences prior to the pandemic are also those at highest risk for negative consequences of COVID-19 $(25,59,60)$. This heightened risk has been attributed to the numerous social, health, and environmental conditions which place racial minorities and low SES individuals at disparate 
risk of the negative effects of COVID-19 via poor access to medical care, (quality) health insurance, or healthy foods; inequality in education and income; living in highly segregated, disenfranchised neighborhoods with poor quality housing and greater exposure to pollution; and more $(21,22,27,57,61)$. Moreover, these groups disproportionately comprise the "essential" or "frontline" worker category, which limits their ability to work from home $(23,26)$. Thus, the COVID-19 pandemic is highlighting deeply embedded social and structural inequities that contribute to health differences in the U.S.

\section{Limitations}

Our results should be interpreted in light of limitations. First, within each block group there could be higher mobile phones usage for those of higher SES (30). Low SES individuals may be unable to pay for cell phones and bills, and older individuals may not use locationtransmitting cell phones $(62,63)$. This may lead to an overestimation of the percentage of residents staying at home among these demographics. Relatedly, mobile phone location data may have larger errors in low-SES areas due to poor quality of GPS signals or noises. However, assuming these issues exist to a comparable extent across Census regions, our observed regional differences in physical distancing hold.

Second, our measure of physical distancing does not include other virus avoidance practices (e.g., mask-wearing; maintaining six feet of distance from others). It is possible that individuals or groups may adhere to some practices but not others; for instance, if individuals cannot stay at home, they may instead practice mask-wearing at higher rates. Examination of their stay-at-home practices would therefore be an incomplete characterization of physical distancing. Additionally, SafeGraph's definition of "home" may lead to larger measurement errors for dense urban areas where residents typically reside in small apartment buildings than 
for less urban areas. Moreover, the implication of staying completely at "home" for urban and rural residents may differ, considering the large difference in population density.

Third, due to data limitation, there is a temporal gap between the ACS data (2015-2019) and the physical distancing data (2020). It is possible that the racial composition and SES for some Census block groups may have changed in the past several years, and therefore the sociodemographic characteristics matched to some Census block groups may be inaccurate. However, existing studies suggest that neighborhood and/or Census block group characteristics change slowly over time or actively stabilize. Neighborhoods have been shown to have stabilizing rates of chronic poverty or persisting affluence over the past few decades (64). Moreover, a review of neighborhood change from the past 50 years showed that the most common pathway of neighborhood trajectories was no change at all (65).

Fourth, our preliminary analyses by Census division and state in Appendix Figures 2 and 3 suggest that the variations within each Census region may be even greater than those between the regions. Future studies should expand our analyses to further compare physical distancing patterns at the Census division or state level. Finally, this study primarily demonstrates the descriptive patterns of regional differences in physical distancing. Future studies should examine the causal determinants.

\section{Conclusion}

Results from our study can be used by policymakers and politicians to guide plans for reopening. Despite concerns regarding COVID-19-related disparities in cases, hospitalizations, and deaths, there is limited evidence on how reopening policies disparately impact society (56). This has led to calls for research that not only identifies the determinants of these disparities, but also that proposes policy approaches to mitigate them $(66,67)$. Our analysis of location data 
suggests that some COVID-19 differences may be avoidable if short-term policy decisions address the amount of mobility allowed. Officials in high-risk areas may choose to adopt policies that will reduce infection densities by supporting improvements in, for example, income support, paid leave policies that allow essential workers to limit their mobility when sick, access to workplace infection protection for essential workers, and access to free and available COVID-19 testing (56).

Future research should study physical distancing along the axes of social stratification that we consider here. In addition to the dimensions considered in this study, when data become available, future studies can further examine the disparities among Census block groups by other important dimensions such as political affiliations and religion. Research is needed at the individual level to account for these intersecting barriers to health and well-being, to examine physical distancing alongside personal hygiene practices (e.g., handwashing), and to ensure representativeness in a noninvasive manner. To the extent possible, approaches should combine interview, ethnography, and survey methodologies to examine physical distancing with greater nuance and thorough noninvasive practices, complementing the results from our study which used quantitative methods and a particularly large dataset. 


\section{References}

1. Yong E. How the Pandemic Defeated America: The Atlantic; 2020 [Available from: www.theatlantic.com/magazine/archive/2020/09/coronavirus-american-failure/614191/.

2. CDC. COVID Data Tracker Atlanta, GA: Centers for Disease Control and Prevention; 2021 [Available from: https://covid.cdc.gov/covid-data-tracker/\#datatracker-home.

3. Courtemanche C, Garuccio J, Le A, Pinkston J, Yelowitz A. Strong Social Distancing Measures in the United States Reduced the COVID-19 Growth Rate. Health Affairs. 2020;39(7):1237-46.

4. Lewnard JA, Lo NC. Scientific and Ethical Basis for Social-Distancing Interventions Against COVID-19. The Lancet Infectious Diseases. 2020;20(6):631-3.

5. Koo JR, Cook AR, Park M, Sun Y, Sun H, Lim JT, et al. Interventions to Mitigate Early Spread of SARS-CoV-2 in Singapore: A Modelling Study. The Lancet Infectious Diseases. 2020;20(6):678-88.

6. Pan A, Liu L, Wang C, Guo H, Hao X, Wang Q, et al. Association of Public Health Interventions With the Epidemiology of the COVID-19 Outbreak in Wuhan, China. Jama. 2020;323(19):1915-23.

7. Messner W, Payson SE. Variation in COVID-19 Outbreaks at U.S. State and County Levels. Public Health. 2020;187:15-8.

8. Ahmad K, Erqou S, Shah N, Nazir U, Morrison AR, Choudhary G, et al. Association of Poor Housing Conditions with COVID-19 Incidence and Mortality Across US Counties. PloS one. 2020;15(11):e0241327.

9. Oster AM, Kang GJ, Cha AE, Beresovsky V, Rose CE, Rainisch G, et al. Trends in Number and Distribution of COVID-19 Hotspot Counties - United States, March 8-July 15, 2020. MMWR Morbidity and Mortality Weekly Report. 2020;69(33):1127-32.

10. Chin T, Kahn R, Li R, Chen JT, Krieger N, Buckee CO, et al. US-County Level Variation in Intersecting Individual, Household and Community Characteristics Relevant to COVID-19 and Planning an Equitable Response: A Cross-Sectional Analysis. BMJ Open. 2020;10(9):e039886.

11. Liao Y, Greenlund KJ, Croft JB, Keenan NL, Giles WH. Factors Explaining Excess Stroke Prevalence in the US Stroke Belt. Stroke. 2009;40(10):3336-41.

12. Dobis EA, Stephens HM, Skidmore M, Goetz SJ. Explaining the Spatial Variation in American Life Expectancy. Social Science \& Medicine. 2020;246:112759.

13. Vierboom YC, Preston SH, Hendi AS. Rising Geographic Inequality in Mortality in the United States. SSM - Population Health. 2019;9:100478. 
14. Montez JK, Beckfield J, Cooney JK, Grumbach JM, Hayward MD, Koytak HZ, et al. US State Policies, Politics, and Life Expectancy. The Milbank Quarterly. 2020:1-32.

15. Montez JK, Hayward MD, Wolf DA. Do U.S. States' Socioeconomic and Policy Contexts Shape Adult Disability? Social Science \& Medicine. 2017;178:115-26.

16. Zang E, Lynch SM, West JS. Regional Differences in the Impact of Diabetes on Population Health in the USA. Journal of Epidemiology and Community Health. 2020;75:56-61.

17. Minahan J, Valdivieso E, Johnson D, Baker TA. Health Disparities: Are They Regional? A Descriptive Analysis of Older Adults in the United States. Innovation in Aging. 2017;1(Suppl $1): 319$.

18. Bourassa KJ, Sbarra DA, Caspi A, Moffitt TE. Social Distancing as a Health Behavior: County-Level Movement in the United States During the COVID-19 Pandemic Is Associated with Conventional Health Behaviors. Annals of Behavioral Medicine. 2020;54(8):548-56.

19. Baker RS. Why is the American South Poorer? Social Forces. 2019;99(1):126-54.

20. Weill JA, Stigler M, Deschenes O, Springborn MR. Social Distancing Responses to COVID-19 Emergency Declarations Strongly Differentiated by Income. Proceedings of the National Academy of Sciences. 2020;117(33):19658-60.

21. CDC. Health Equity Considerations and Racial and Ethnic Minority Groups Atlanta, GA: Centers for Disease Control and Prevention; 2020 [Available from: www.cdc.gov/coronavirus/2019-ncov/need-extra-precautions/racial-ethnic-minorities.html.

22. Yancy CW. COVID-19 and African Americans. Jama. 2020;323(19):1891-2.

23. U.S. Bureau of Labor Statistics. Labor Force Characteristics by Race and Ethnicity, 2018. www.bls.gov/opub/reports/race-and-ethnicity/2018/home.htm; 2019.

24. Lyttelton T, Zang E. Sickness-Related Absences During the COVID-19 Pandemic: The Role of Occupations. SocArXiv. 2020.

25. Bailey ZD, Moon JR. Racism and the Political Economy of COVID-19: Will We Continue to Resurrect the Past? Journal of Health Politics, Policy and Law. 2020;45(6):937-50.

26. Gould E, Wilson V. Black Workers Face Two of the Most Lethal Preexisting Conditions for Coronavirus-Racism and Economic Inequality 2020 [Available from: www.epi.org/publication/black-workers-covid/.

27. Jacobs DE. Environmental Health Disparities in Housing. American Journal of Public Health. 2011;101(Suppl 1):S115-22.

28. Blair H, Worker J. Southern State Policymakers Must Do More to Respond to the Coronavirus Pandemic 2020 [Available from: www.epi.org/blog/southern-state-policymakers- 
must-do-more-to-respond-to-the-coronavirus-pandemic-medicaid-expansion-emergency-paidsick-leave-and-dedicated-public-health-resources-are-especially-needed/.

29. Palmer JR, Espenshade TJ, Bartumeus F, Chung CY, Ozgencil NE, Li K. New Approaches to Human Mobility: Using Mobile Phones for Demographic Research. Demography. 2013;50(3):1105-28.

30. Kishore N, Kiang MV, Engø-Monsen K, Vembar N, Schroeder A, Balsari S, et al. Measuring Mobility to Monitor Travel and Physical Distancing Interventions: A Common Framework for Mobile Phone Data Analysis. The Lancet Digital Health. 2020;2(11):e622-e8.

31. Siedner MJ, Harling G, Reynolds Z, Gilbert RF, Haneuse S, Venkataramani AS, et al. Social Distancing to Slow the US COVID-19 Epidemic: Longitudinal Pretest-Posttest Comparison Group Study. PLOS Medicine. 2020;17(8):e1003244.

32. Gao S, Rao J, Kang Y, Liang Y, Kruse J, Dopfer D, et al. Association of Mobile Phone Location Data Indications of Travel and Stay-at-Home Mandates With COVID-19 Infection Rates in the US. JAMA Network Open. 2020;3(9):e2020485-e.

33. Sehra ST, George M, Wiebe DJ, Fundin S, Baker JF. Cell Phone Activity in Categories of Places and Associations With Growth in Cases of COVID-19 in the US. JAMA Intern Med. 2020;180(12):1614-20.

34. Kavanagh NM, Goel RR, Venkataramani AS. County-Level Socioeconomic and Political Predictors of Distancing for COVID-19. American Journal of Preventive Medicine. 2021(Preprint).

35. Jay J, Bor J, Nsoesie EO, Lipson SK, Jones DK, Galea S, et al. Neighbourhood Income and Physical Distancing during the COVID-19 Pandemic in the United States. Nature Human Behaviour. 2020;4(12):1294-302.

36. Gao S, Rao J, Kang Y, Liang Y, Kruse J. Mapping County-Level Mobility Pattern Changes in the United States in Response to COVID-19. SIGSpatial Special. 2020;12(1):16-26.

37. Squire RF. Quantifying Sampling Bias in SafeGraph Patterns colab.research.google.com2019 [Available from: https://colab.research.google.com/drive/1u15afRytJMsizySFqA2EPIXSh3KTmNTQ\#offline=tru e\&sandboxMode=true.

38. Simonov A, Sacher SK, Dubé J-PH, Biswas S. The Persuasive Effect of Fox News: NonCompliance with Social Distancing During the Covid-19 Pandemic. National Bureau of Economic Research. 2020;No. w27237.

39. SafeGraph. Social Distancing Metrics 2020 [Available from: https://docs.safegraph.com/docs/social-distancing-metrics.

40. Krieger N, Chen JT, Waterman PD, Soobader MJ, Subramanian SV, Carson R. Geocoding and Monitoring of US Socioeconomic Inequalities in Mortality and Cancer 
Incidence: Does the Choice of Area-Based Measure and Geographic Level Matter?: The Public Health Disparities Geocoding Project. American Journal of Epidemiology. 2002;156(5):471-82.

41. U.S. Census Bureau. Statistical Groupings of States and Counties. https://www2.census.gov/geo/pdfs/reference/GARM/Ch6GARM.pdf; 2018.

42. DeAre DR. Geographical Mobility: March 1990 to March 1991. U.S. Bureau of the Census, Current Population Reports, Washington, DC: U.S. Government Printing Office; 1992.

43. Ratcliffe M, Burd C, Holder K, Fields A. Defining Rural at the U.S. Census Bureau: American Community Survey and Geography Brief. https://www2.census.gov/geo/pdfs/reference/ua/Defining_Rural.pdf: Washington, D.C.: U.S. Census Bureau; 2016.

44. Raifman J, Nocka K, Jones D, Bor J, Lipson S, Jay J, et al. COVID-19 US State Policy Database. Ann Arbor, MI: Inter-University Consortium for Political and Social Research; 2021.

45. Kendi IX. Stop Blaming Black People for Dying of the Coronavirus: The Atlantic; 2020 [Available from: www.theatlantic.com/ideas/archive/2020/04/race-and-blame/609946/.

46. Henry-Nickie M, Hudak J. Social Distancing in Black and White Neighborhoods in Detroit: A Data-Driven Look at Vulnerable Communities: Brookings; 2020 [Available from: www.brookings.edu/blog/fixgov/2020/05/19/social-distancing-in-black-and-whiteneighborhoods-in-detroit-a-data-driven-look-at-vulnerable-communities/.

47. Breslau J, Finucane ML, Locker AR, Baird MD, Roth EA, Collins RL. A Longitudinal Study of Psychological Distress in the United States Before and During the COVID-19 Pandemic. Preventive Medicine. 2021;143:106362.

48. Hong Y-R, Lawrence J, Williams Jr D, Mainous Iii A. Population-Level Interest and Telehealth Capacity of US Hospitals in Response to COVID-19: Cross-Sectional Analysis of Google Search and National Hospital Survey Data. JMIR Public Health Surveillance. 2020;6(2):e18961.

49. Shang J, Chastain AM, Perera UGE, Quigley DD, Fu CJ, Dick AW, et al. COVID-19 Preparedness in US Home Health Care Agencies. Journal of the American Medical Directors Association. 2020;21(7):924-7.

50. Boehmer TK, DeVies J, Caruso E, van Santen KL, Tang S, Black CL, et al. Changing Age Distribution of the COVID-19 Pandemic - United States, May-August 2020. MMWR Morbidity and Mortality Weekly Report. 2020;69(39):1404-9.

51. Avendano M, Kawachi I. Why Do Americans Have Shorter Life Expectancy and Worse Health Than Do People in Other High-Income Countries? Annual review of public health. 2014;35(1):307-25. 
52. Barnett JC, Vornovitsky MS. Health Insurance Coverage in the United States: 2015. Current Population Reports, P60-257(RV), U.S. Government Printing Office, Washington, D.C.; 2016.

53. Bitler M, Hoynes H, Schanzenbach DW. Why the Safety Net Might Not Respond as Effectively to COVID-19 As It Should. The Milbank Quarterly Opinion. 2020.

54. Wykoff R. The Intergenerational Cycles of Rural Health. American Journal of Public Health. 2020;110(9):1279-80.

55. Haynes S. COVID-19 Is Prompting Wealthy People to Move Out of Cities. The Plague Had the Same Effect Hundreds of Years Ago 2020 [Available from:

https://time.com/5851978/pandemic-plague-henry-viii/.

56. Chang S, Pierson E, Koh PW, Gerardin J, Redbird B, Grusky D, et al. Mobility Network Models of COVID-19 Explain Inequities and Inform Reopening. Nature. 2021;589(7840):82-7.

57. Williams DR, Collins C. Racial Residential Segregation: A Fundamental Cause of Racial Disparities in Health. Public Health Reports. 2001;116(5):404-16.

58. Phelan JC, Link BG. Is Racism a Fundamental Cause of Inequalities in Health? Annual Review of Sociology. 2015;41(1):311-30.

59. Bowleg L. We're Not All in This Together: On COVID-19, Intersectionality, and Structural Inequality. American Journal of Public Health. 2020:e1-e.

60. Dorn Av, Cooney RE, Sabin ML. COVID-19 Exacerbating Inequalities in the US. The Lancet. 2020;395(10232):1243-4.

61. Woolf SH, Braveman P. Where Health Disparities Begin: The Role Of Social And Economic Determinants-And Why Current Policies May Make Matters Worse. Health Affairs. 2011;30(10):1852-9.

62. Rashid A, Zeb MA, Rashid A, Anwar S, Joaquim F, Halim Z. Conceptualization of Smartphone Usage and Feature Preferences Among Various Demographics. Cluster Computing. 2020;23(2):1855-73.

63. Laeeq Khan M, Welser HT, Cisneros C, Manatong G, Idris IK. Digital Inequality in the Appalachian Ohio: Understanding How Demographics, Internet Access, and Skills Can Shape Vital Information Use (VIU). Telematics and Informatics. 2020;50(101380):1-18.

64. Solari CD. Affluent Neighborhood Persistence and Change in U.S. Cities. City \& Community. 2012;11(4):370-88.

65. Delmelle EC. Differentiating Pathways of Neighborhood Change in 50 U.S. Metropolitan Areas. Environment and Planning A: Economy and Space. 2017;49(10):2402-24. 
66. Laurencin CT, McClinton A. The COVID-19 Pandemic: A Call to Action to Identify and Address Racial and Ethnic Disparities. Journal of racial and ethnic health disparities.

2020;7(3):398-402.

67. Chowkwanyun M, Reed AL. Racial Health Disparities and Covid-19 - Caution and Context. New England Journal of Medicine. 2020;383(3):201-3. 


\section{Figures}

Figure 1. Stay-at-home patterns by Census region

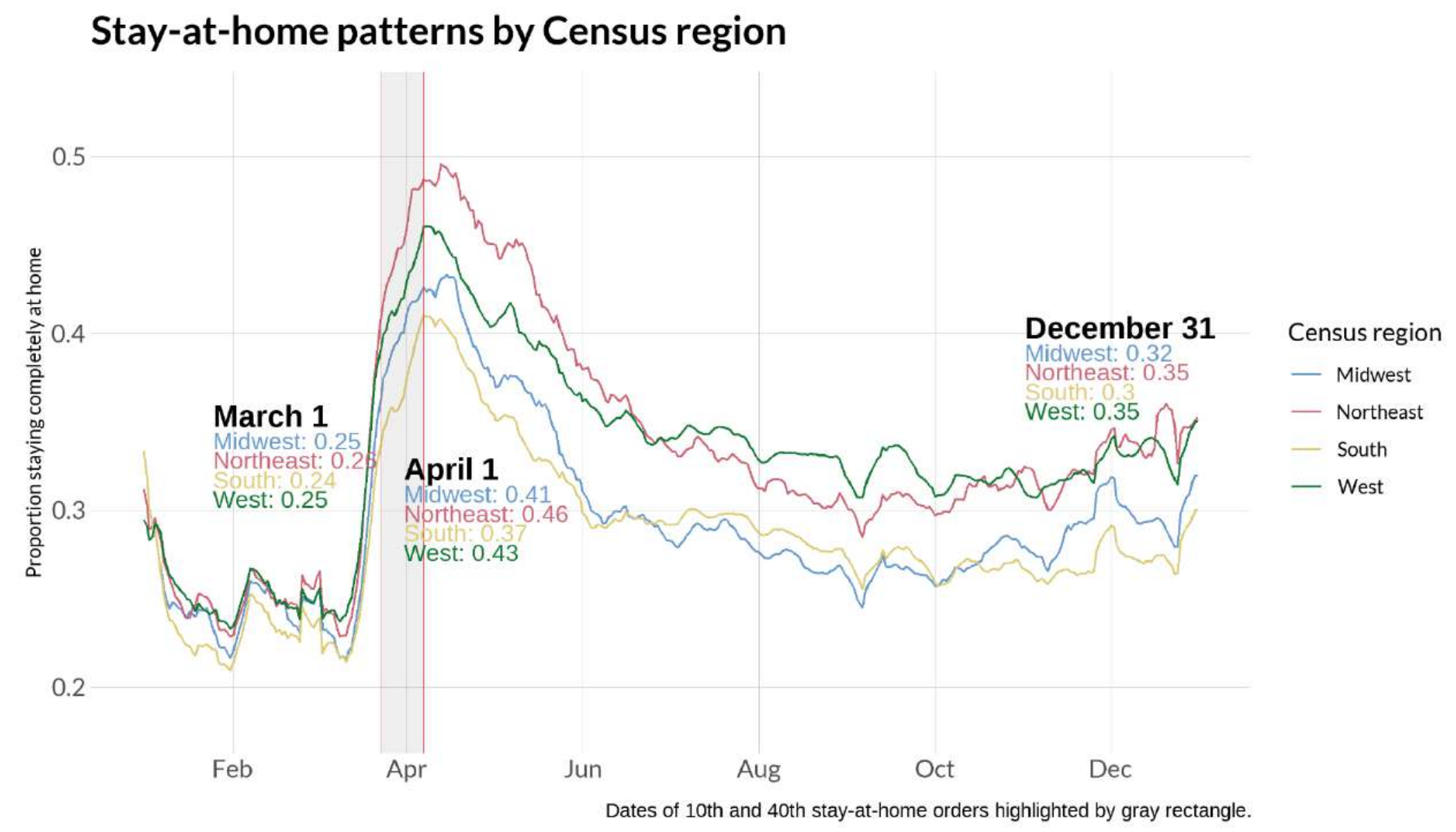


Figure 2. Stay-at-home patterns by Census region and proportion Black

\section{Stay-at-home patterns by Census region and proportion Black}

Midwest

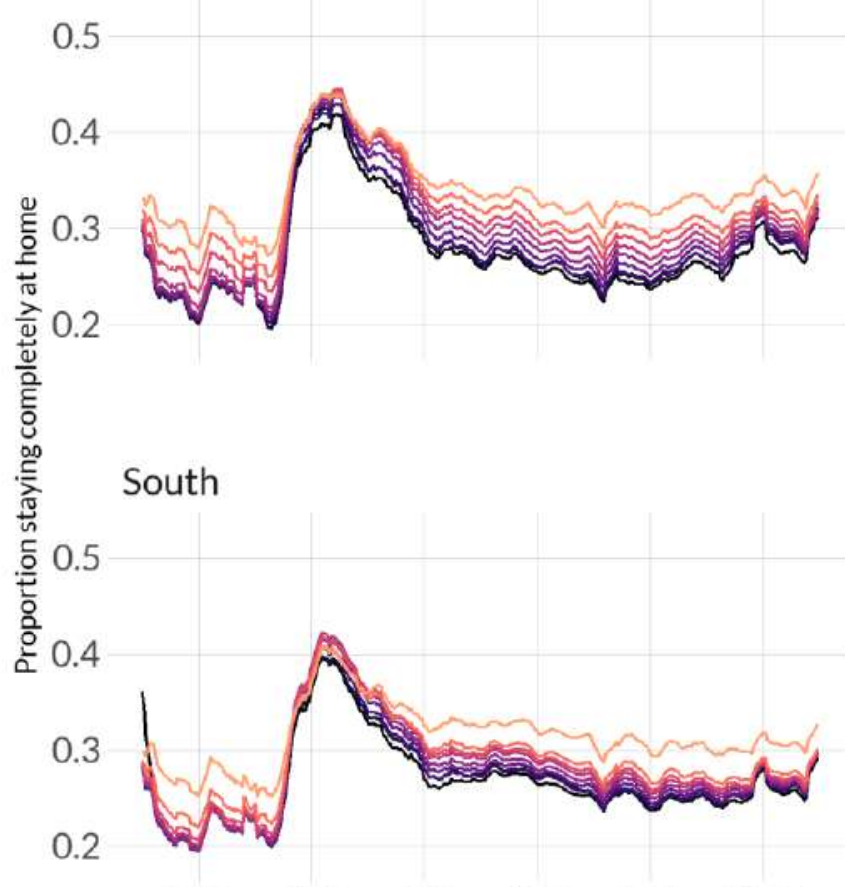

Northeast

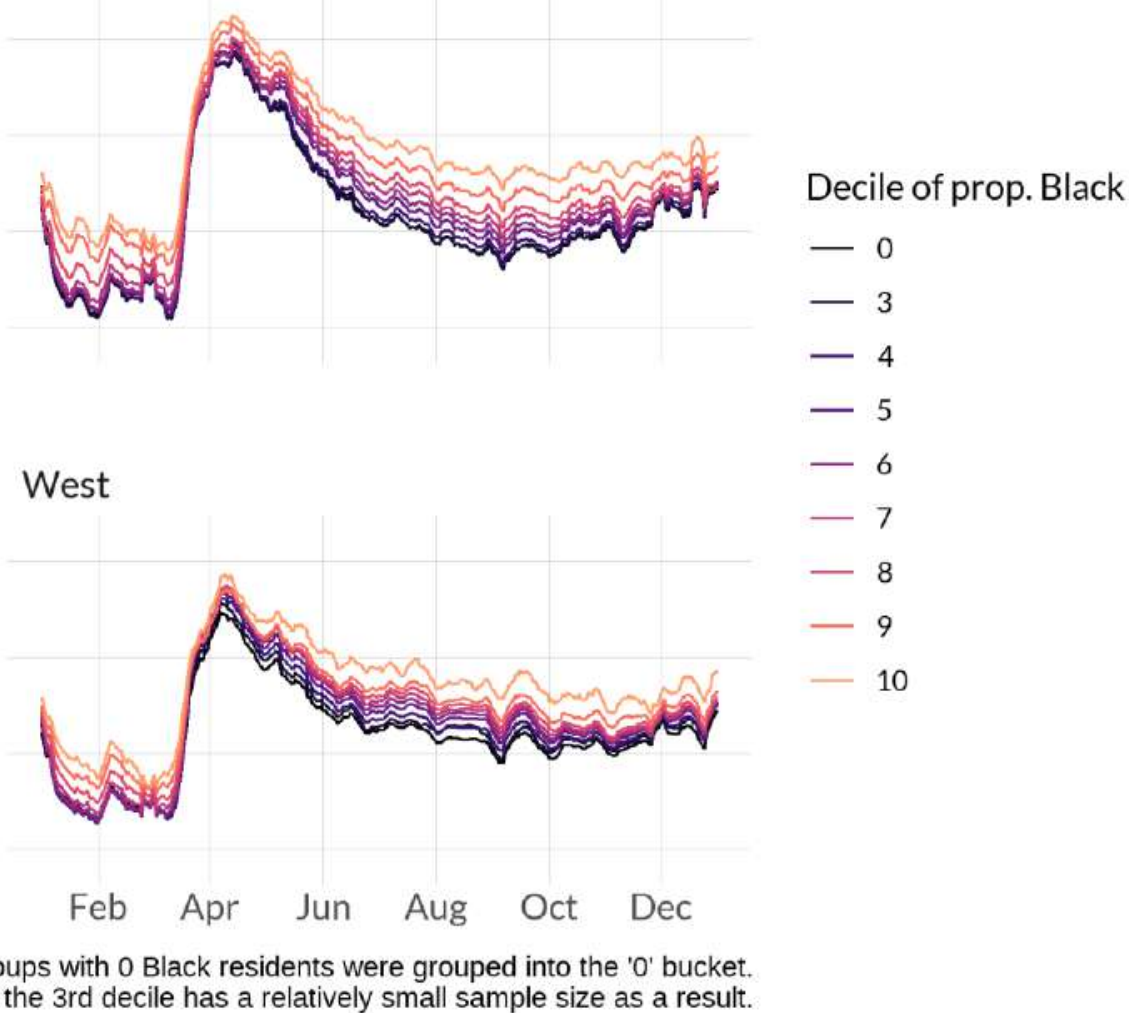


Figure 3. Stay-at-home patterns by race and urban-rural status

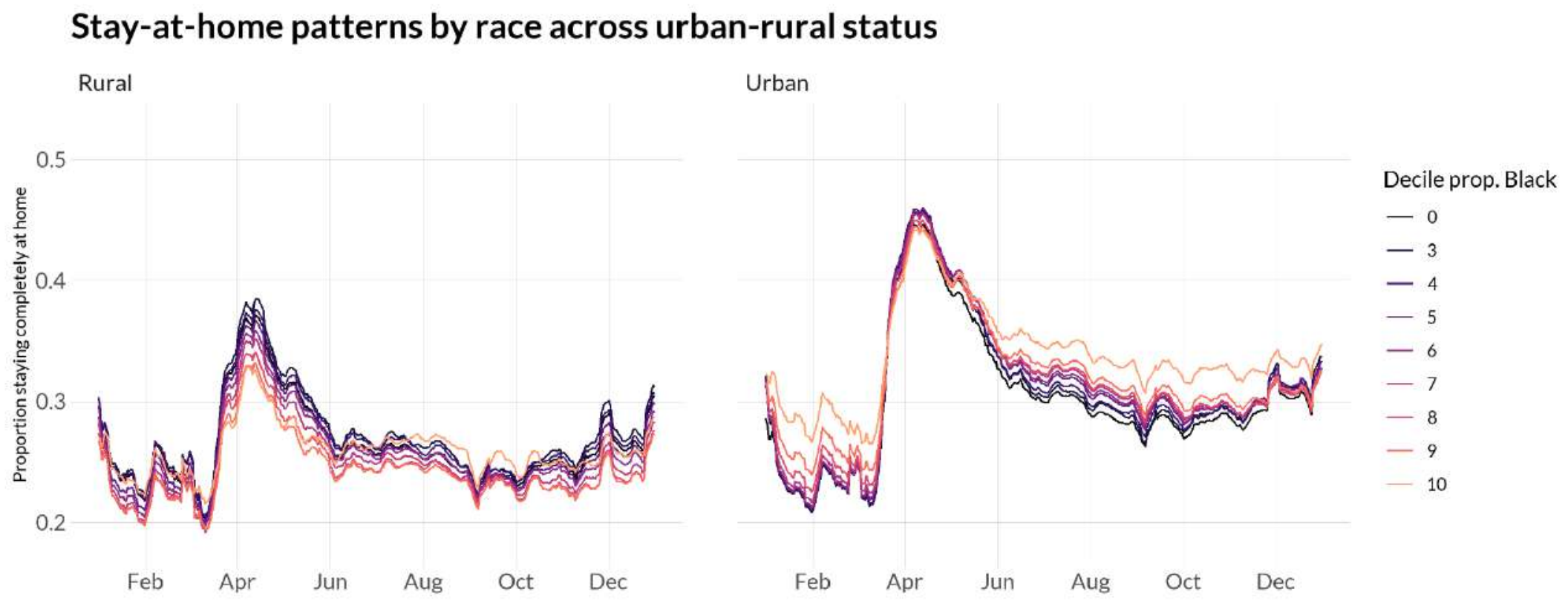




\section{Stay-at-home patterns by Census region and prop. frontline workers}

Midwest

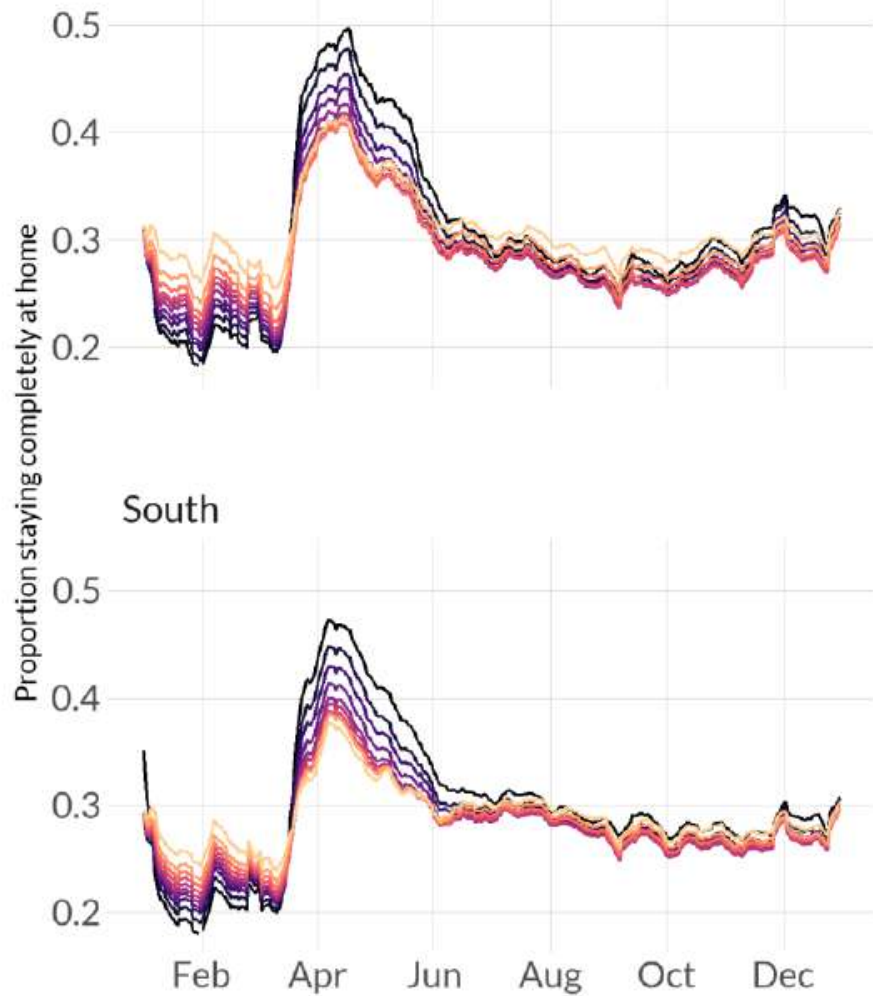

Northeast

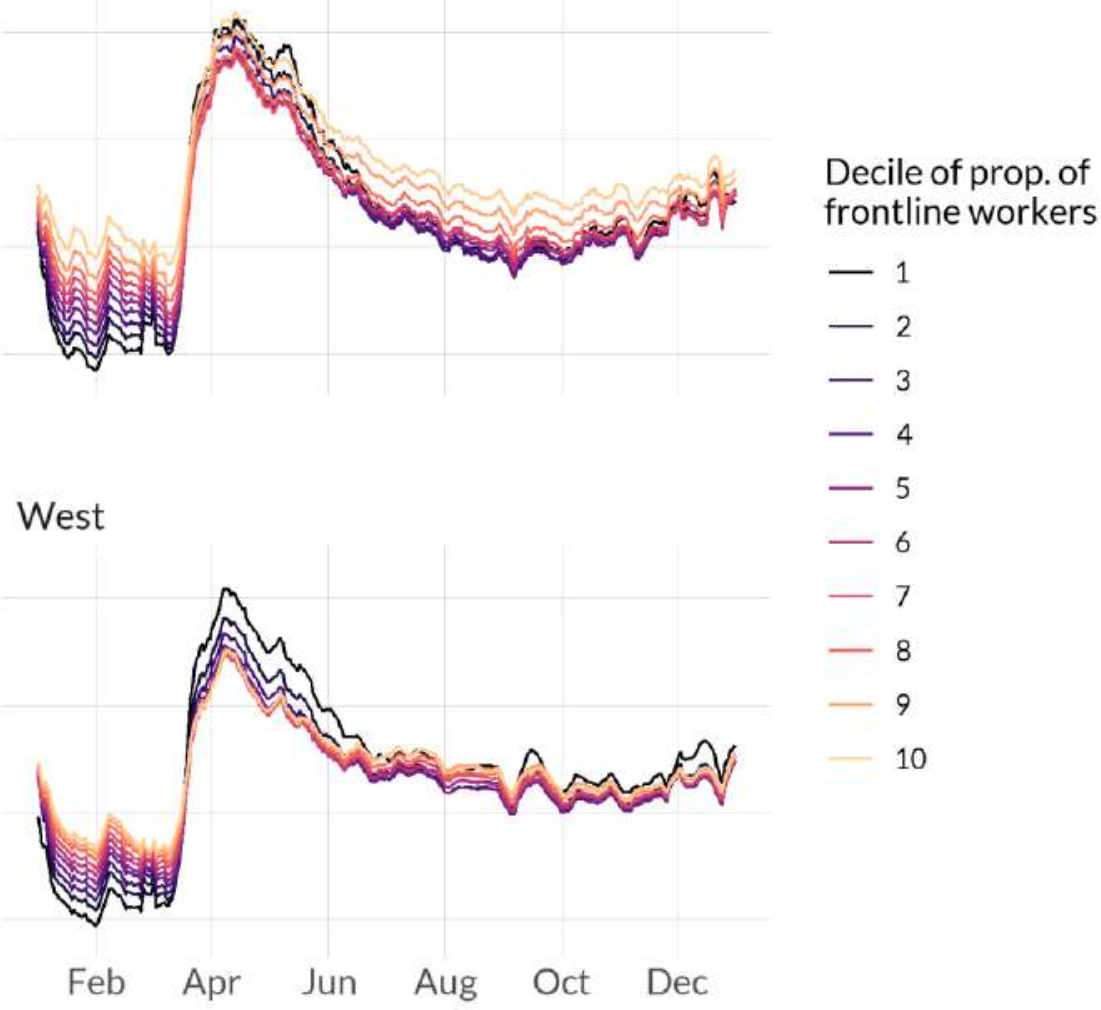




\section{Stay-at-home patterns by Census region and prop. Bachelor's degree holders}

Midwest

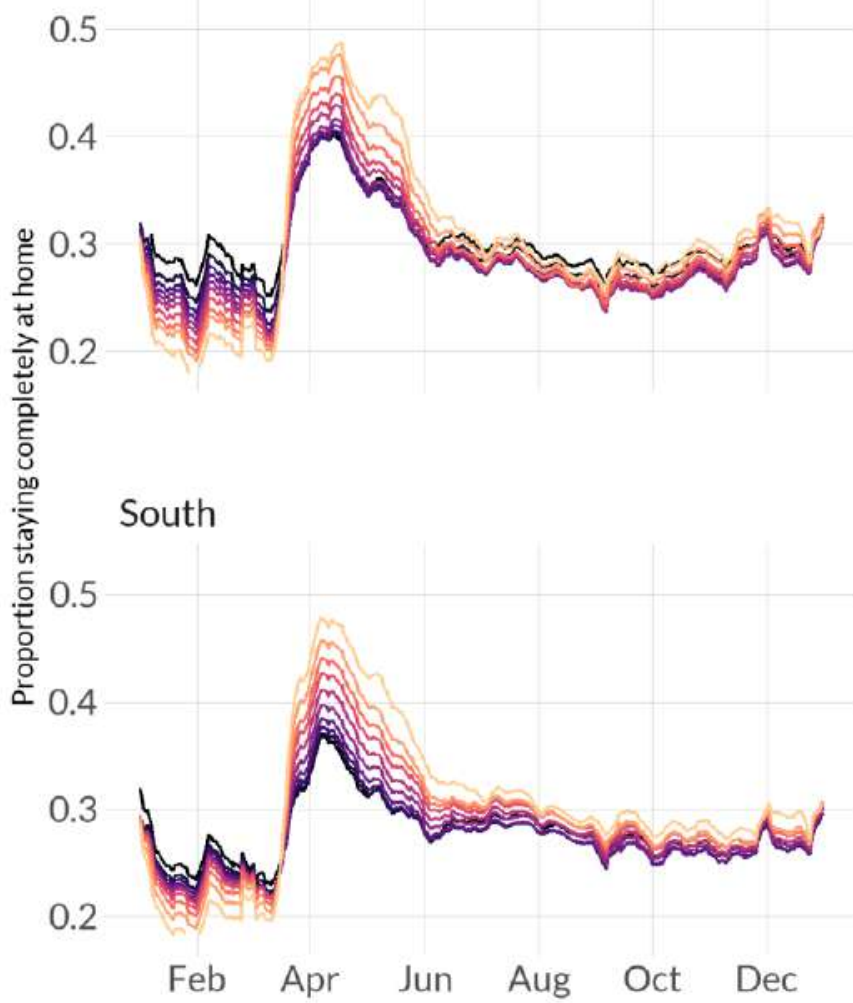

Northeast

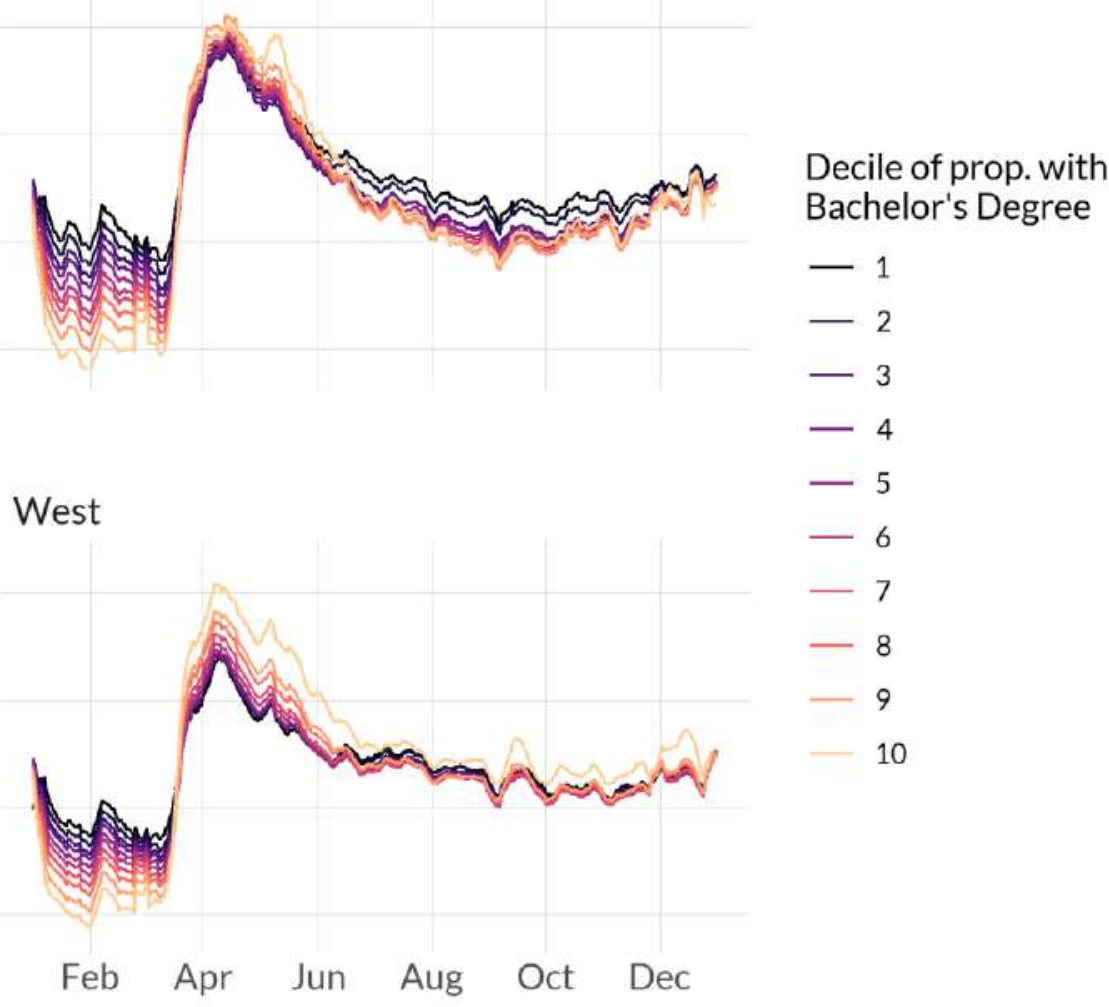




\section{Stay-at-home patterns by income across region}

Midwest

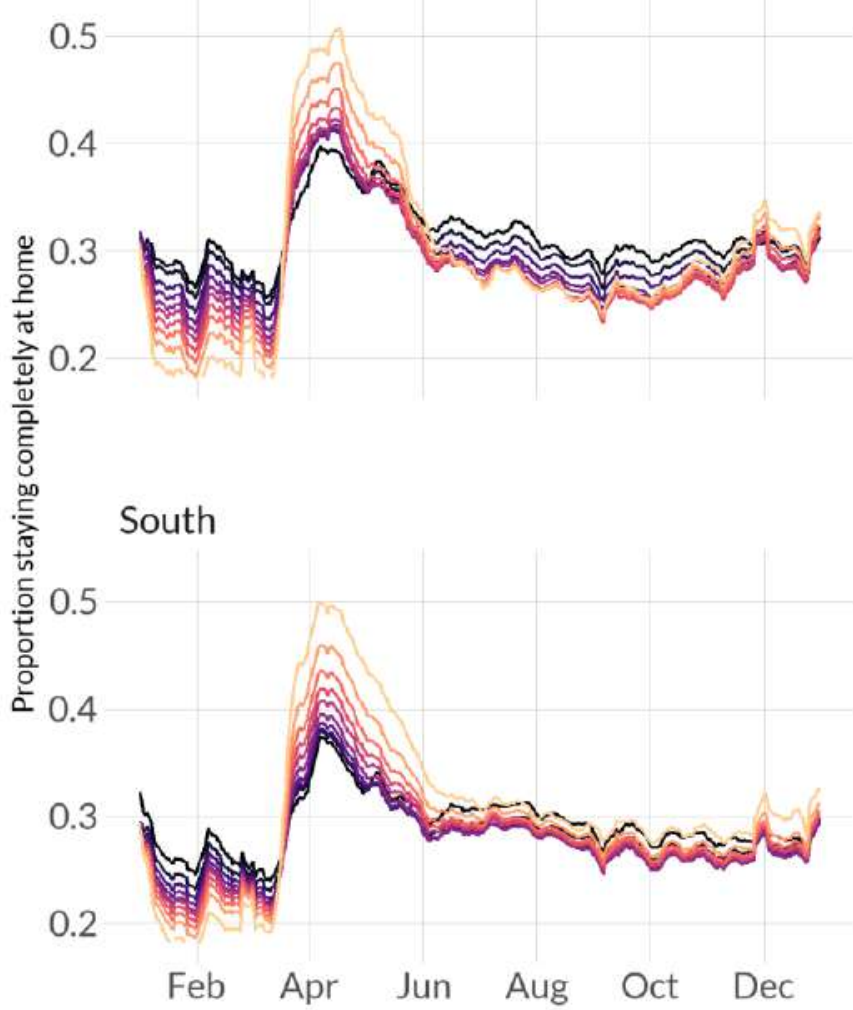

Northeast

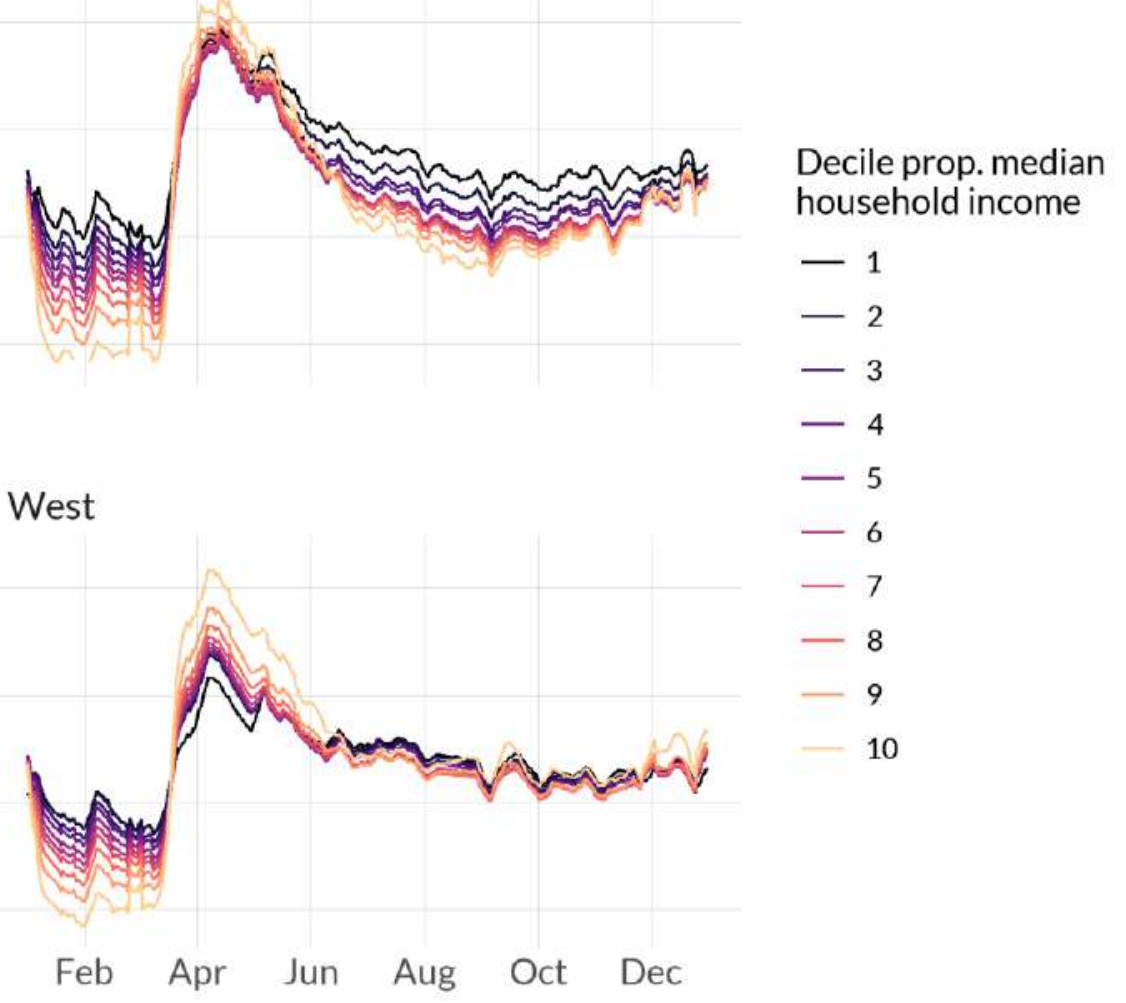




\section{Appendix}

\section{Appendix A1. Alternative Measures of Physical Distancing}

In Appendix Figure 1, we show several alternate measures of physical distancing to the 7-day rolling average of the proportion staying at home, which is the main metric used in our paper. These measures include the median proportion of devices staying home; the difference in stay-at-home proportions between a given date in 2020 and in 2019; the median time spent away from home; and the proportion of devices exhibiting "work behavior," or spending more than three hours away from home between 8 a.m. and 6 p.m. local time (variable documentation online $^{1}$ ).

We firstly show the median proportion of devices staying at home. Given a few block groups in SafeGraph's location data include a disproportionately large number of cell phones for their population, we may overrepresent these few block groups by using the 7-day rolling mean proportion of devices staying home weighted by the total number of devices in each block group. Using the median proportion of devices staying home in each Census region can mitigate this issue. Secondly, we show the proportion staying completely at home relative to the same period last year, to show that our results are consistent in not only trends of stay-at-home patterns but also changing stay-at-home behavior in response to the lockdown orders. Thirdly, we show the median time away from home in minutes. The proportion staying completely at home may exclude those leaving their home for short excursions such as walks or performing necessary activities like grocery shopping. Therefore, it may underestimate the extent of physical distancing. The median time traveled can be an alternate measure distinguishing those that are exposed for longer periods of time and potentially experience higher risks from those who travel only short amounts of time immediately outside of their home. Finally, we show trends in the proportion of devices exhibiting "work behavior." A device exhibiting "work behavior" is defined as any device that spends more than 3 hours at a location outside of their home during 8 a.m. and $6 \mathrm{p} . \mathrm{m}$. local time or stops for more than 20 minutes at more than three locations outside of their geohash-7 home (characterized by SafeGraph as "delivery behavior"). For the median distance traveled from home and the work behavior metrics, we exclude weekends as a smoothing measure for our plots.

The alternative measures of physical distancing shown here are on the whole reflective of results from Figure 1. There is a sharp increase in physical distancing through April across all regions, with the greatest rates of physical distancing at the height of the pandemic across all metrics occurring in the Northeast, and physical distancing trends converging and more broadly lowering as the lockdown goes on.

\section{[Appendix Figure A1 About Here]}

\section{Appendix A2. Definition of Frontline Workers}

We define frontline workers as those occupations with the highest risks for sicknessrelated absences from work in March - June 2020. Specifically, existing studies show that 
sickness-related absences were highly concentrated in the following occupations: service, transportation, production, and material moving occupations ${ }^{2}$. Our detailed coding of the frontline occupations is shown below, based on information provided in Figure 2 in Lyttelton and Zang (2020).

\begin{tabular}{lll} 
Short description & $\begin{array}{l}\text { Variable } \\
\text { codes }\end{array}$ & $\begin{array}{l}\text { "Frontline worker" } \\
\text { definition }\end{array}$ \\
\hline $\begin{array}{l}\text { Service occupations } \\
\text { Production, transportation, and material moving }\end{array}$ & 019,055 & Primary definition \\
occupations & 034,070 & Primary definition \\
Healthcare practitioners and technical occupations & 016,052 & Expanded definition \\
Sales and office occupations & 027,063 & Expanded definition \\
Installation, maintenance, and repair occupations & 033,069 & Expanded definition \\
\hline
\end{tabular}

All codes are taken from table C24010 in the 2014-2018 American Community Survey.

Appendix Figure 4 shows our expanded definition of frontline workers, which includes all occupations in our primary definition of "frontline worker" and in addition healthcare, sales, and maintenance and repair occupations. Our results here are nearly identical to the results shown in Figure 4 with the primary definition of frontline workers, with trends in the Midwest, South, and West suggesting that frontline workers are not able to stay home at the height of the lockdown. This trend is reversed in the Northeast, when differences at the height of the lockdown are small but increase as the lockdown goes on.

\section{[Appendix Figure A4 About Here]}

\section{Appendix A3. Heterogeneity within Each Region}

Results in Appendix Figures A2 and A3 by Census division and state further show considerable variations within and across Census divisions. We observe largest within-region variations in the South Census region - namely, between the East-South-Central and SouthAtlantic Census divisions, which maintained differences in stay-at-home rates of about 0.05 throughout the pandemic despite being indistinguishable before March 2020. Between the EastSouth-Central (South) and the Middle-Atlantic (Northeast) divisions, the difference is even more pronounced, with a 0.16 difference in stay-at-home rates at the beginning of April. Census divisions also differ by the states within them: while the four states in the West-North-Central division are nearly indistinguishable in their stay-at-home rates, much heterogeneity is present in the South-Atlantic division, with a 0.15 difference between Maryland and South Carolina at the beginning of April. 


\section{Reference}

1. SafeGraph. Social Distancing Metrics. 2020; https://docs.safegraph.com/docs/socialdistancing-metrics.

2. Lyttelton T, Zang E. Sickness-related Absences During the COVID-19 Pandemic: The Role of Occupations. 2020. 


\section{Appendix Figures}

Appendix Figure A1. Alternative measures of physical distancing

\section{Alternative metrics of physical distancing}
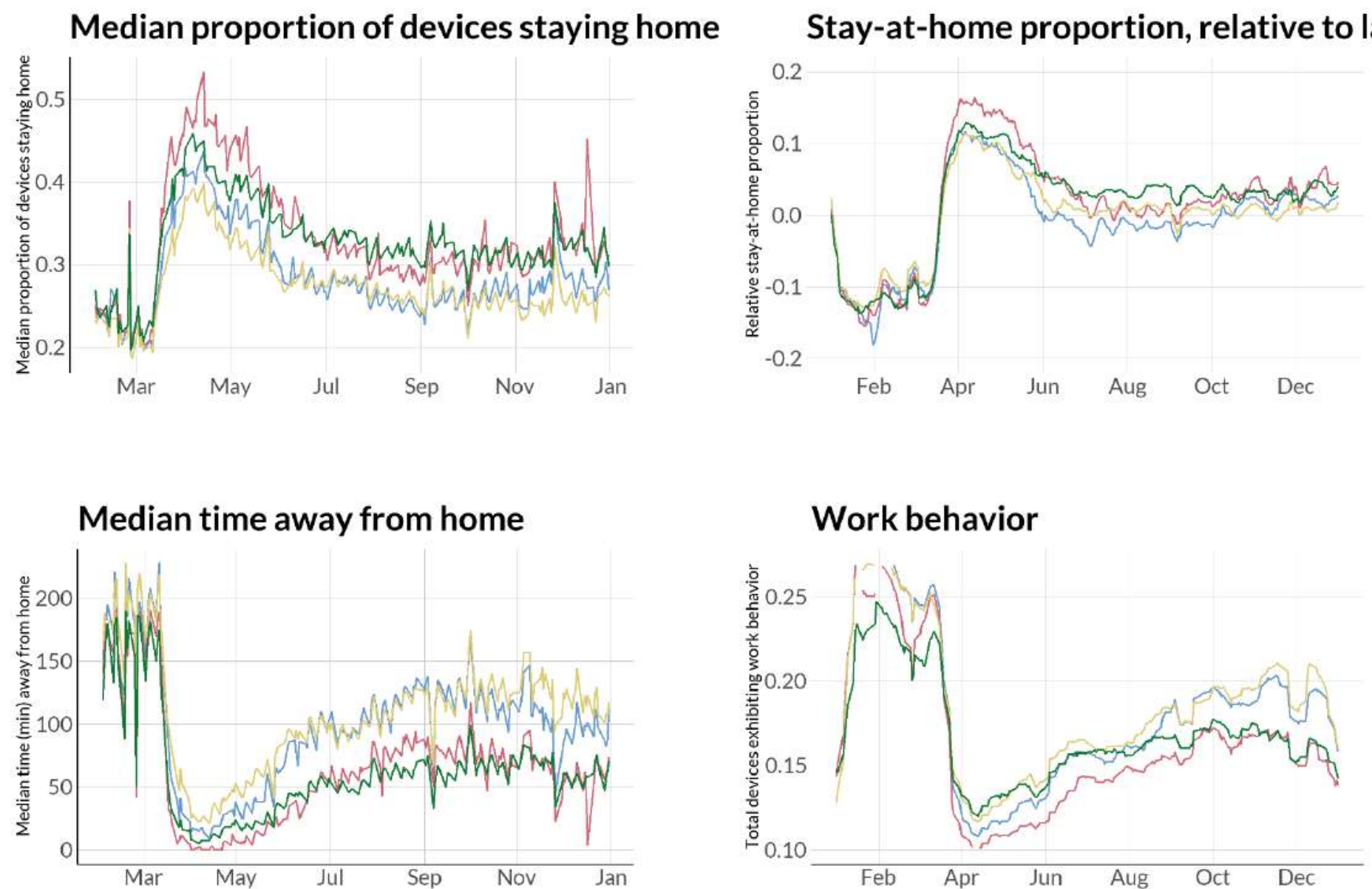

Census region

- Midwest

- Northeast

South 
Appendix Figure A2. Stay-at-home patterns by Census division

\section{Stay-at-home patterns by Census division}

Midwest

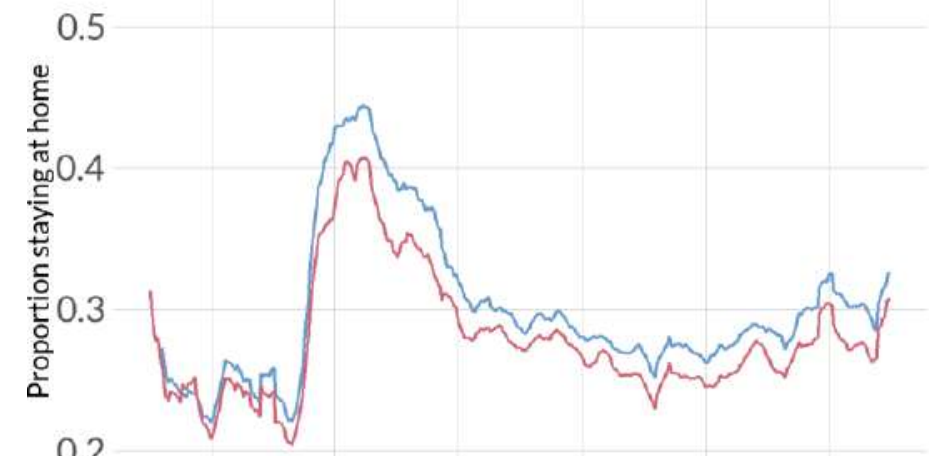

0.2

South

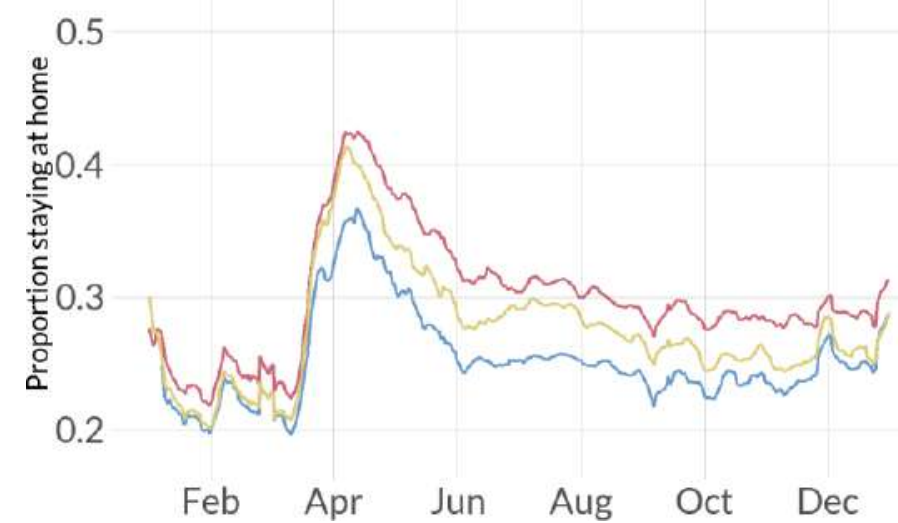

Northeast

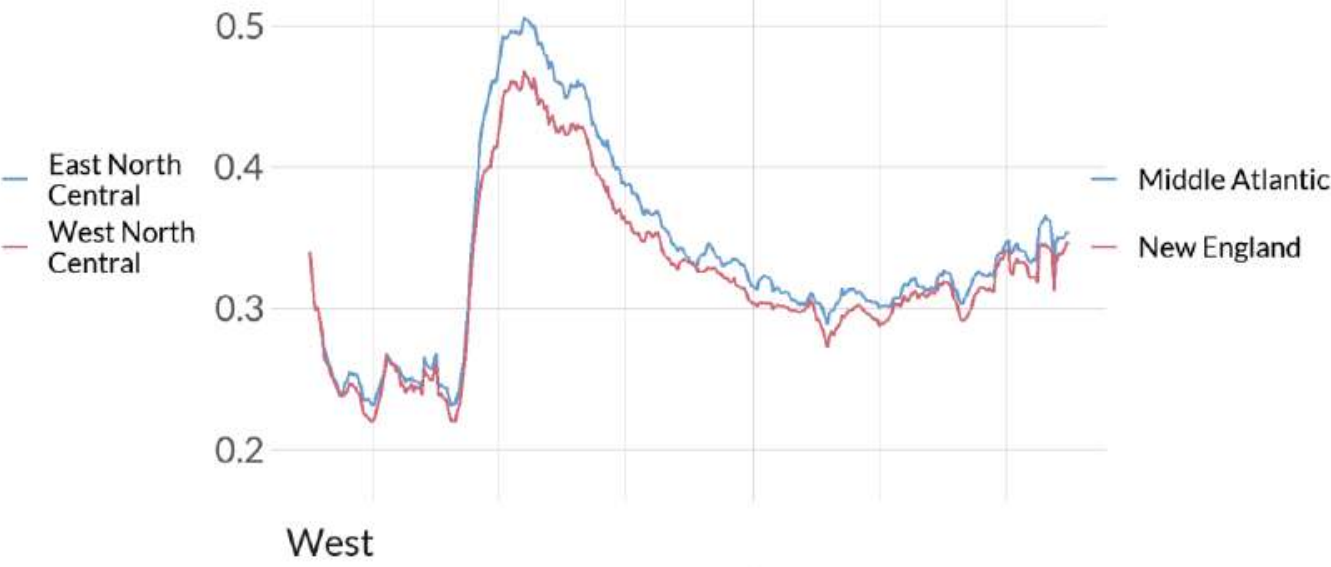

0.5

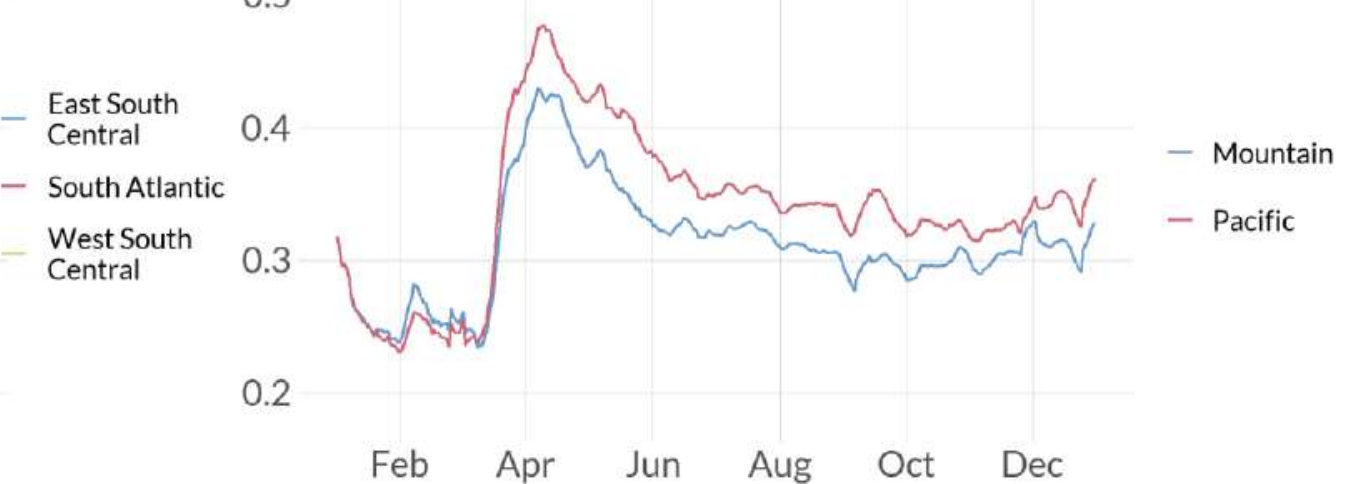


Appendix Figure A3. Stay-at-home patterns by state (vertical lines indicating the timing for stay-at-home orders)

\section{Stay-at-home patterns by state}
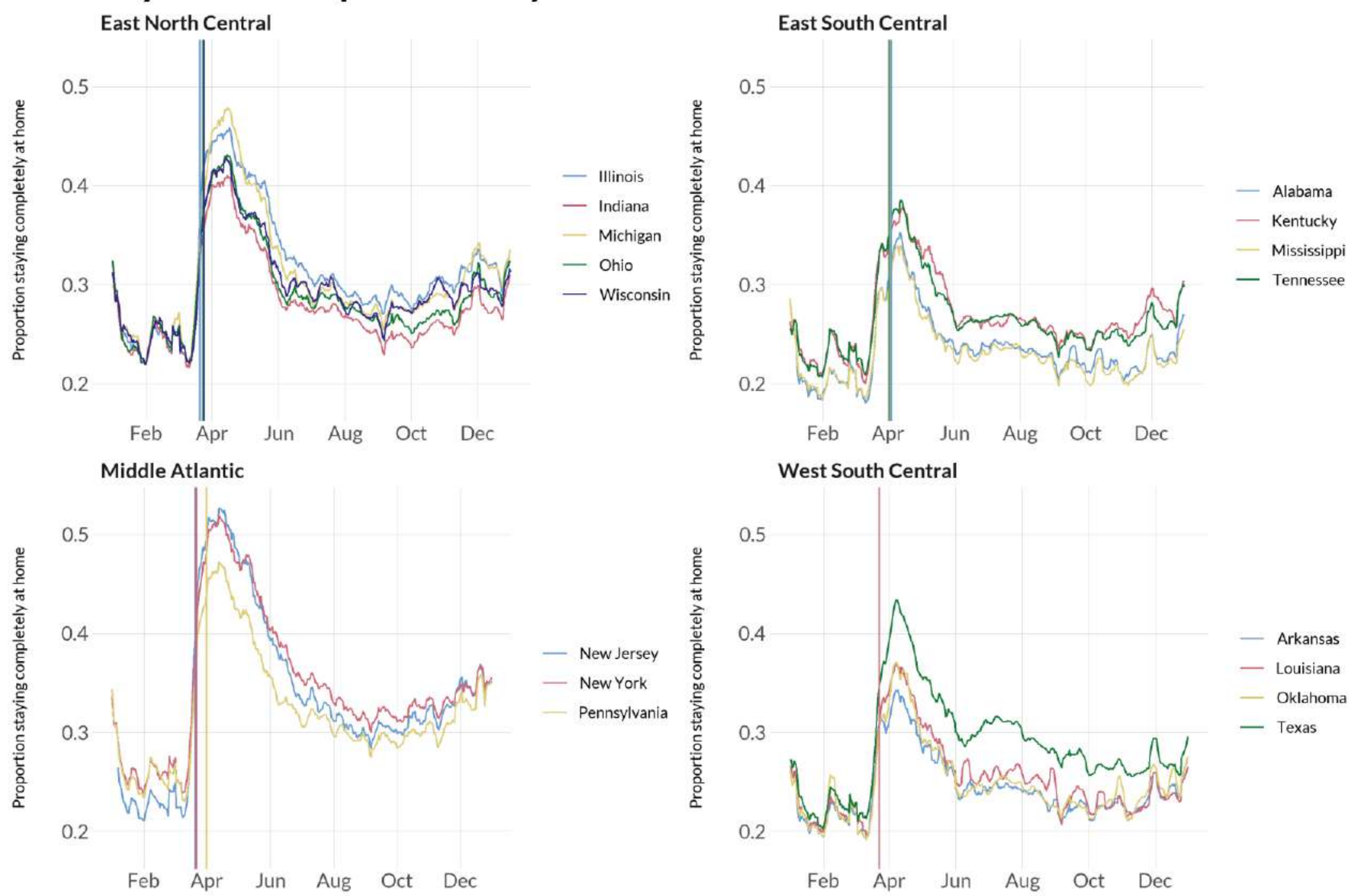


\section{Stay-at-home patterns by state (cont.)}

Mountain
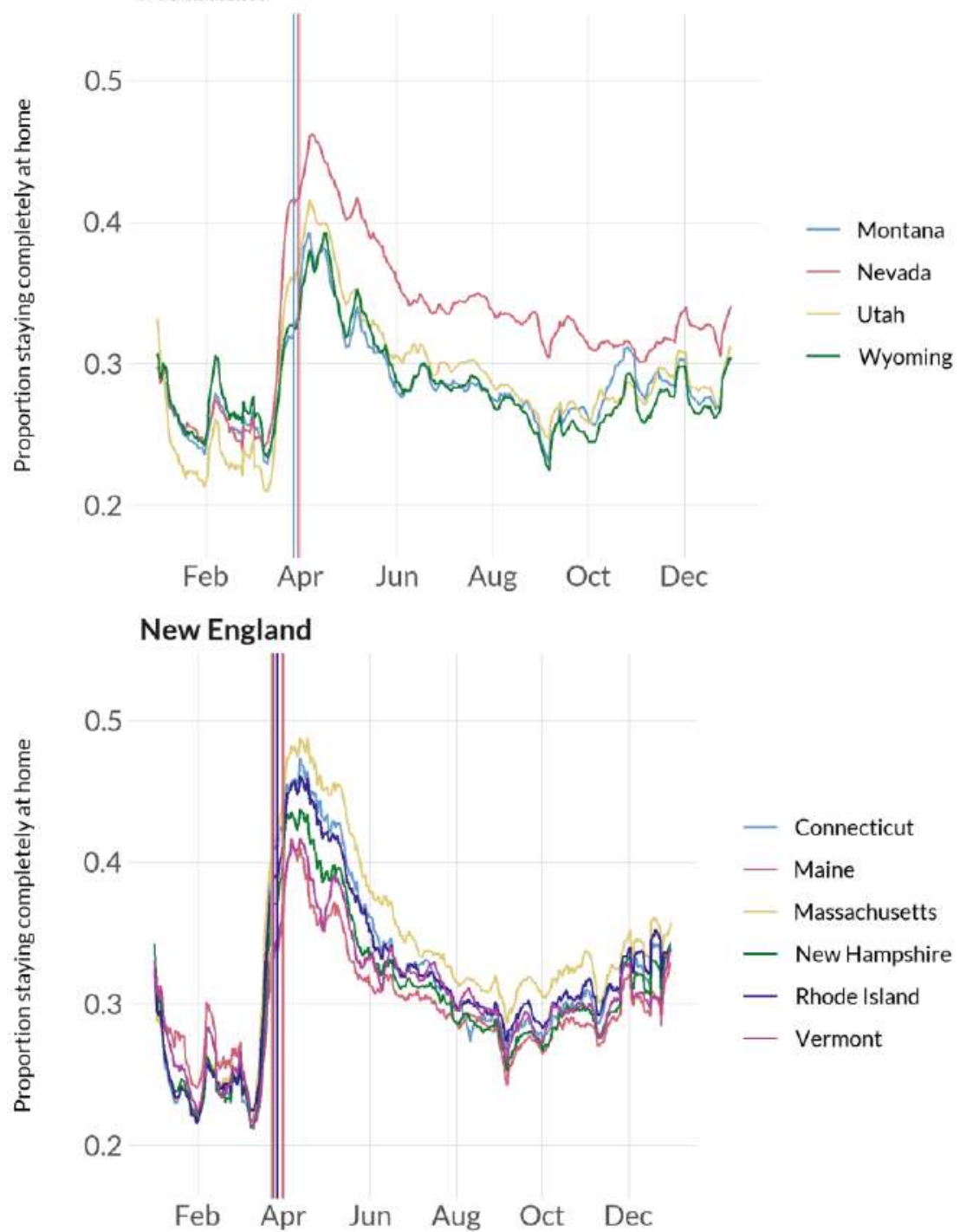

Mountain (cont.)
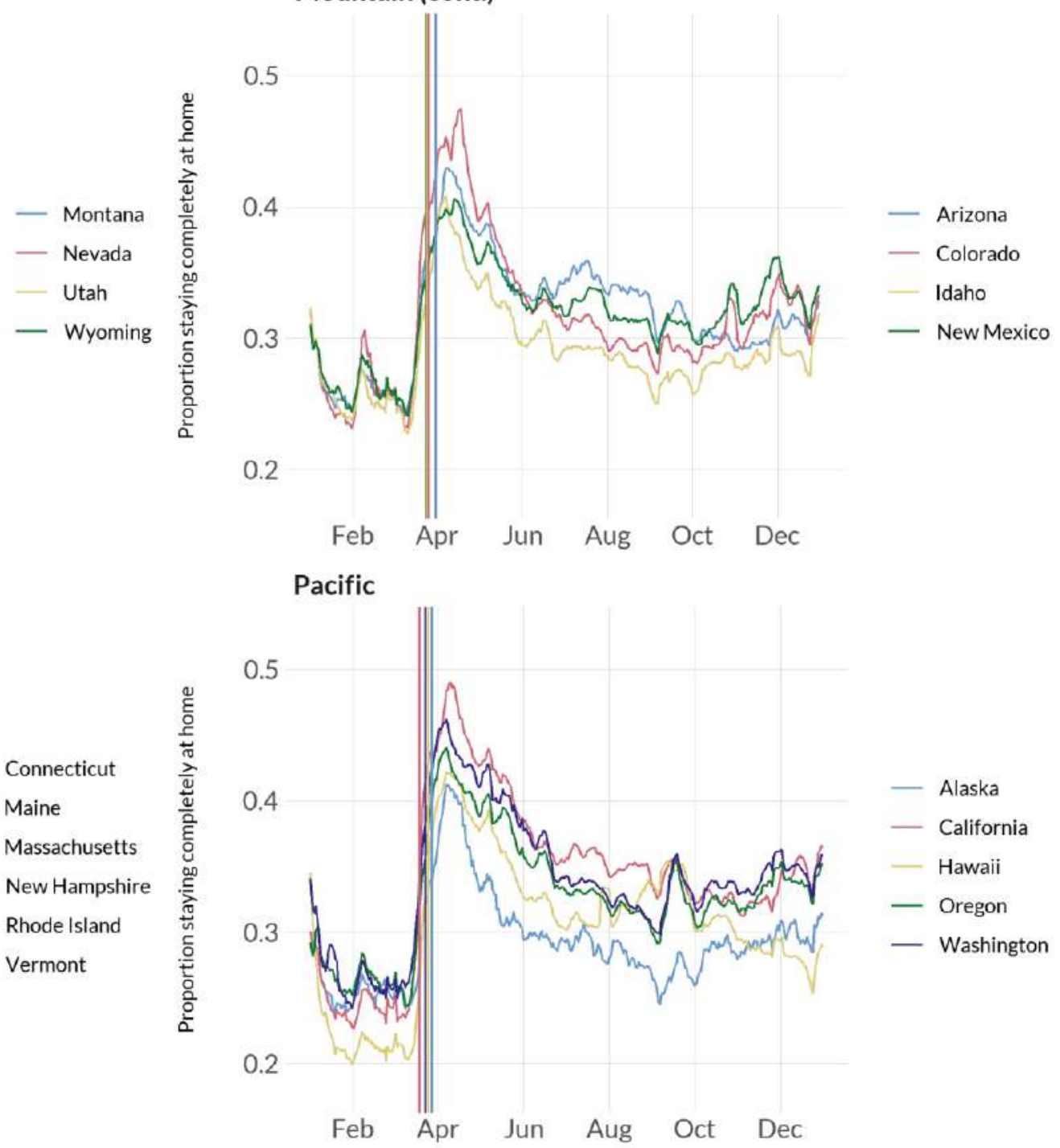


\section{Stay-at-home patterns by state (cont.)}
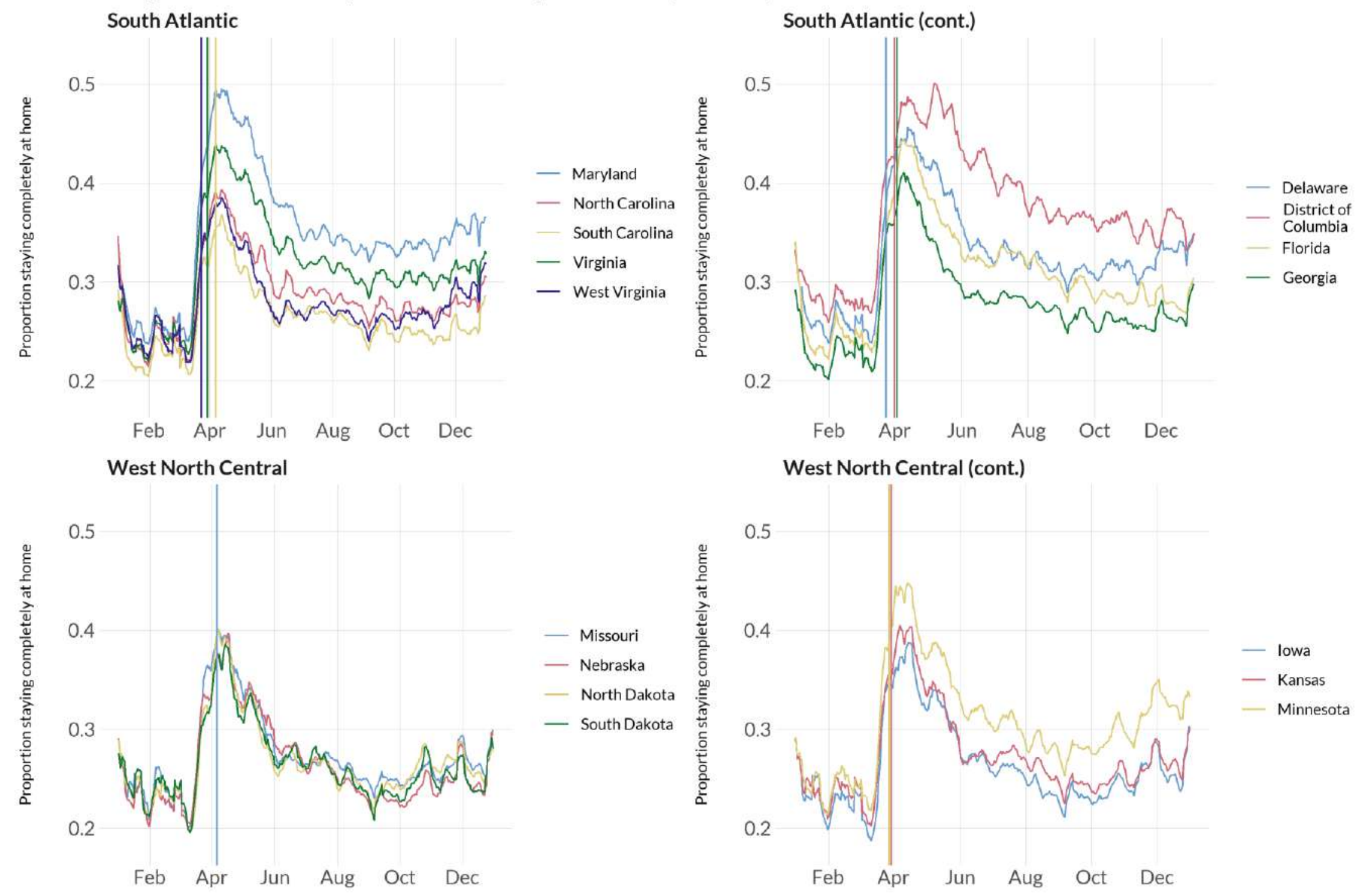
Appendix Figure A4. Stay-at-home proportion by Census region and "frontline worker" proportion, with an expanded definition of "frontline worker"

\section{Stay-at-home patterns by occupation}

Expanded definition of 'frontline workers.'

Midwest

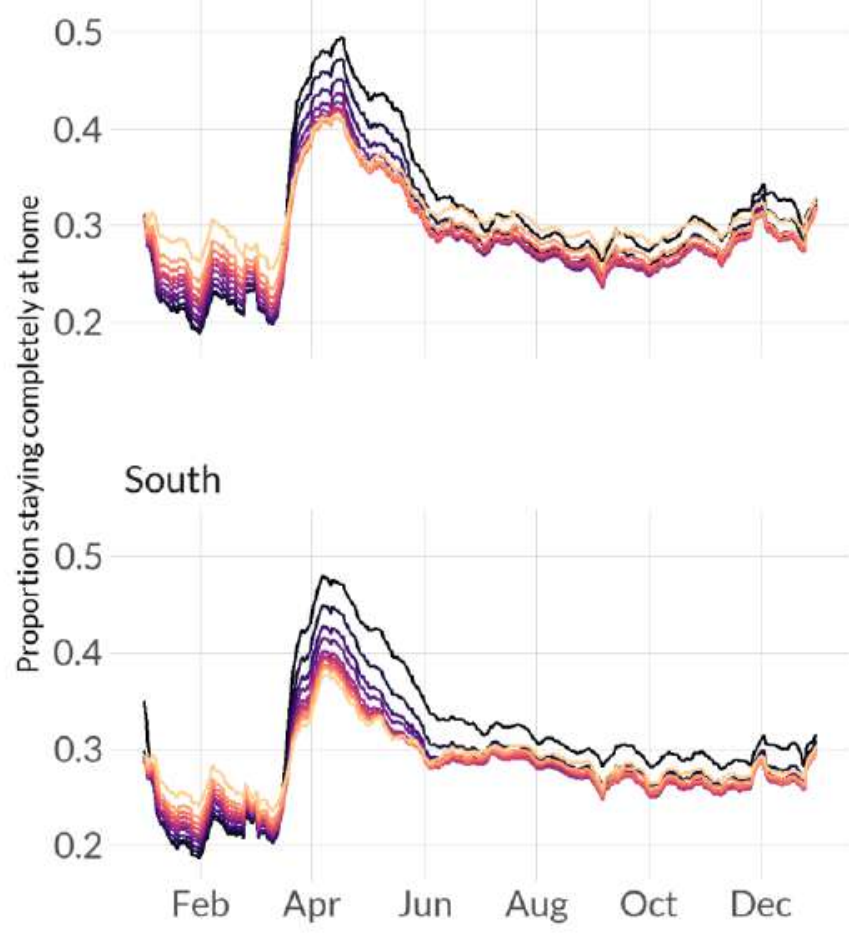

Northeast

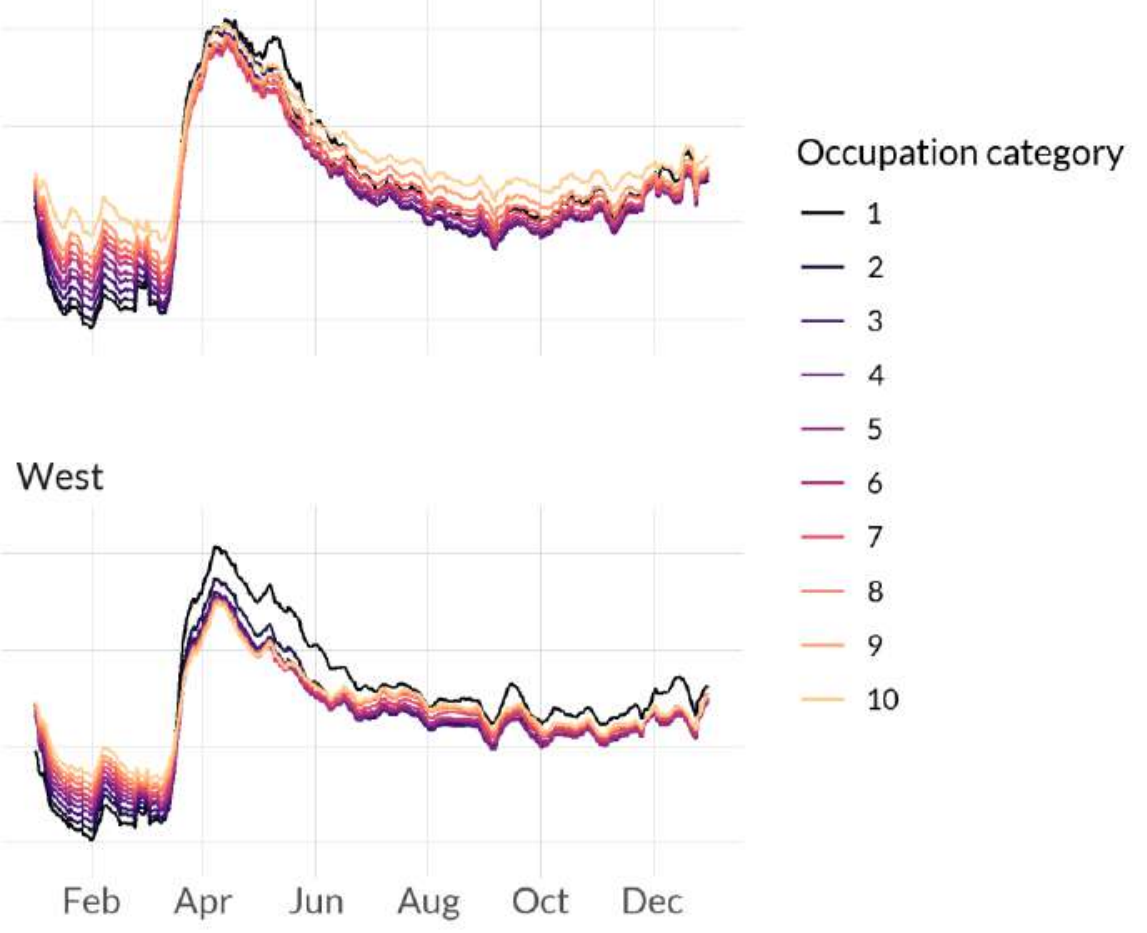




\section{Appendix Tables}

Appendix Table A1. Physical Distancing and Proportion Black, by Region

\begin{tabular}{|c|c|c|c|c|c|c|}
\hline \multirow[b]{2}{*}{ Variable } & \multicolumn{3}{|c|}{ Midwest $(\mathrm{N}=18,899,029$, Adj R-squared=0.19) } & \multicolumn{3}{|c|}{ South $(\mathrm{N}=26,923,163$, Adj R-squared= 0.19) } \\
\hline & Coefficient & SE & $95 \% \mathrm{CI}$ & Coefficient & SE & $95 \% \mathrm{CI}$ \\
\hline \multicolumn{7}{|l|}{ Days from January 1 st } \\
\hline Linear term & $-2.33 \mathrm{E}-04$ & $1.40 \mathrm{E}-06$ & $(-2.36 \mathrm{E}-04,-2.31 \mathrm{E}-04)$ & $1.29 \mathrm{E}-04$ & $1.16 \mathrm{E}-06$ & $(1.27 \mathrm{E}-04,1.31 \mathrm{E}-04)$ \\
\hline Quadratic term & $2.17 \mathrm{E}-07$ & $2.98 \mathrm{E}-09$ & $(2.11 \mathrm{E}-07,2.22 \mathrm{E}-07)$ & $-6.52 \mathrm{E}-07$ & 2.47E-09 & $(-6.57 \mathrm{E}-07,-6.47 \mathrm{E}-07)$ \\
\hline Proportion Black & 0.076 & $1.53 \mathrm{E}-04$ & $(0.076,0.077)$ & 0.06 & $1.14 \mathrm{E}-04$ & $(0.060,0.061)$ \\
\hline \multicolumn{7}{|l|}{ Period $($ Reference $=$ Before April 1st $)$} \\
\hline April 1st-30th & 0.158 & $9.83 \mathrm{E}-05$ & $(0.158,0.158)$ & 0.139 & $8.83 \mathrm{E}-05$ & $(0.139,0.139)$ \\
\hline After May 1st & 0.059 & $1.18 \mathrm{E}-04$ & $(0.059,0.059)$ & 0.047 & $9.98 \mathrm{E}-05$ & $(0.047,0.047)$ \\
\hline \multicolumn{7}{|l|}{$\begin{array}{l}\text { Interaction between period and proportion } \\
\text { Black }\end{array}$} \\
\hline April 1st - April 30th * proportion Black & -0.049 & $3.00 \mathrm{E}-04$ & $(-0.050,-0.049)$ & -0.066 & 2.23E-04 & $(-0.066,-0.065)$ \\
\hline After May 1st * proportion Black & -0.003 & $1.78 \mathrm{E}-04$ & $(-0.003,-0.002)$ & -0.004 & $1.32 \mathrm{E}-04$ & $(-0.004,-0.004)$ \\
\hline \multirow[t]{3}{*}{ Intercept } & 0.263 & $6.57 \mathrm{E}-05$ & $(0.263,0.263)$ & 0.231 & $5.72 \mathrm{E}-05$ & $(0.231,0.231)$ \\
\hline & \multicolumn{3}{|c|}{ Northeast $(\mathrm{N}=15,035,157$, Adj R-squared $=0.25)$} & \multicolumn{3}{|c|}{ West $(\mathrm{N}=16,733,365$, Adj R-squared=0.23) } \\
\hline & Coefficient & SE & $95 \% \mathrm{CI}$ & Coefficient & SE & $95 \% \mathrm{CI}$ \\
\hline \multicolumn{7}{|l|}{ Days from January $1 \mathrm{st}$} \\
\hline Linear term & $-2.30 \mathrm{E}-04$ & $1.80 \mathrm{E}-06$ & $(-2.33 \mathrm{E}-04,-2.26 \mathrm{E}-04)$ & $2.22 \mathrm{E}-04$ & $1.57 \mathrm{E}-06$ & (2.19E-04,2.25E-04) \\
\hline Quadratic term & $-1.89 \mathrm{E}-08$ & $3.83 \mathrm{E}-09$ & $(-2.65 \mathrm{E}-08,-1.14 \mathrm{E}-08)$ & $-8.87 \mathrm{E}-07$ & 3.34E-09 & $(-8.93 \mathrm{E}-07,-8.80 \mathrm{E}-07)$ \\
\hline Proportion Black & 0.088 & $2.20 \mathrm{E}-04$ & $(0.087,0.088)$ & 0.089 & $4.86 \mathrm{E}-04$ & $(0.088,0.090)$ \\
\hline \multicolumn{7}{|l|}{ Period $($ Reference $=$ Before April 1st $)$} \\
\hline April 1st-30th & 0.212 & $1.28 \mathrm{E}-04$ & $(0.212,0.213)$ & 0.15 & $1.10 \mathrm{E}-04$ & $(0.150,0.151)$ \\
\hline After May 1st & 0.102 & $1.52 \mathrm{E}-04$ & $(0.102,0.103)$ & 0.069 & $1.32 \mathrm{E}-04$ & $(0.068,0.069)$ \\
\hline \multicolumn{7}{|l|}{$\begin{array}{l}\text { Interaction between period and proportion } \\
\text { Black }\end{array}$} \\
\hline April 1st - April 30th * proportion Black & -0.033 & 4.32E-04 & $(-0.034,-0.032)$ & -0.002 & $9.51 \mathrm{E}-04$ & $(-0.004,0.000)$ \\
\hline After May 1 st $*$ proportion Black & 0.006 & $2.56 \mathrm{E}-04$ & $(0.006,0.007)$ & 0.027 & 5.64E-04 & $(0.025,0.028)$ \\
\hline Intercept & 0.275 & $8.52 \mathrm{E}-05$ & $(0.275,0.275)$ & 0.261 & 7.37E-05 & $(0.261,0.261)$ \\
\hline
\end{tabular}

Note: All p-values are smaller than 0.001 . 
Appendix Table A2. Physical Distancing and the Proportion of Frontline Workers, by Region

\begin{tabular}{|c|c|c|c|c|c|c|}
\hline \multirow[b]{2}{*}{ Variable } & \multicolumn{3}{|c|}{ Midwest $(\mathrm{N}=18,897,847$, Adj R-squared= 0.19) } & \multicolumn{3}{|c|}{ South $(\mathrm{N}=26,906,238$, Adj R-squared= 0.17) } \\
\hline & Coefficient & SE & $95 \% \mathrm{CI}$ & Coefficient & SE & $95 \% \mathrm{CI}$ \\
\hline \multicolumn{7}{|l|}{ Days from January 1 st } \\
\hline Linear term & $-2.33 \mathrm{E}-04$ & $1.42 \mathrm{E}-06$ & $(-2.36 \mathrm{E}-04,-2.30 \mathrm{E}-04)$ & $1.29 \mathrm{E}-04$ & $1.17 \mathrm{E}-06$ & $(1.27 \mathrm{E}-04,1.32 \mathrm{E}-04)$ \\
\hline Quadratic term & $2.16 \mathrm{E}-07$ & 3.03E-09 & $(2.10 \mathrm{E}-07,2.22 \mathrm{E}-07)$ & $-6.53 \mathrm{E}-07$ & $2.50 \mathrm{E}-09$ & $(-6.58 \mathrm{E}-07,-6.48 \mathrm{E}-07)$ \\
\hline Proportion of frontline workers & 0.092 & $2.40 \mathrm{E}-04$ & $(0.091,0.092)$ & 0.054 & $1.95 \mathrm{E}-04$ & $(0.054,0.055)$ \\
\hline \multicolumn{7}{|l|}{ Period $($ Reference $=$ Before April 1st $)$} \\
\hline April 1st-30th & 0.225 & $1.93 \mathrm{E}-04$ & $(0.225,0.226)$ & 0.196 & $1.49 \mathrm{E}-04$ & $(0.196,0.197)$ \\
\hline After May 1st & 0.088 & $1.55 \mathrm{E}-04$ & $(0.087,0.088)$ & 0.069 & $1.23 \mathrm{E}-04$ & $(0.069,0.069)$ \\
\hline \multicolumn{7}{|l|}{$\begin{array}{l}\text { Interaction between period and proportion } \\
\text { of Bachelor's degree holders }\end{array}$} \\
\hline April 1st-30th * prop. frontline workers & -0.204 & 4.69E-04 & $(-0.205,-0.203)$ & -0.21 & $3.82 \mathrm{E}-04$ & $(-0.211,-0.210)$ \\
\hline After May 1 st $*$ prop. frontline workers & -0.081 & 2.78E-04 & $(-0.082,-0.081)$ & -0.068 & $2.27 \mathrm{E}-04$ & $(-0.069,-0.068)$ \\
\hline \multirow[t]{3}{*}{ Intercept } & 0.239 & 1.07E-04 & $(0.239,0.240)$ & 0.225 & $8.40 \mathrm{E}-05$ & $(0.225,0.225)$ \\
\hline & \multicolumn{3}{|c|}{ Northeast $(\mathrm{N}=15,027,003$, Adj R-squared $=0.26)$} & \multicolumn{3}{|c|}{ West $(\mathrm{N}=16,711,234$, Adj R-squared=0.22) } \\
\hline & Coefficient & $\mathrm{SE}$ & $95 \% \mathrm{CI}$ & Coefficient & $\mathrm{SE}$ & $95 \% \mathrm{CI}$ \\
\hline \multicolumn{7}{|l|}{ Days from January 1 st } \\
\hline Linear term & $-2.30 \mathrm{E}-04$ & $1.82 \mathrm{E}-06$ & $(-2.33 \mathrm{E}-04,-2.26 \mathrm{E}-04)$ & $2.23 \mathrm{E}-04$ & $1.57 \mathrm{E}-06$ & $(2.20 \mathrm{E}-04,2.26 \mathrm{E}-04)$ \\
\hline Quadratic term & $-1.90 \mathrm{E}-08$ & 3.88E-09 & $(-2.66 \mathrm{E}-08,-1.14 \mathrm{E}-08)$ & $-8.89 \mathrm{E}-07$ & $3.34 \mathrm{E}-09$ & $(-8.96 \mathrm{E}-07,-8.83 \mathrm{E}-07)$ \\
\hline Proportion of frontline workers & 0.144 & 2.99E-04 & $(0.143,0.145)$ & 0.09 & $2.75 \mathrm{E}-04$ & $(0.090,0.091)$ \\
\hline \multicolumn{7}{|l|}{ Period $($ Reference $=$ Before April 1st $)$} \\
\hline April 1st-30th & 0.26 & 2.17E-04 & $(0.259,0.260)$ & 0.207 & $1.95 \mathrm{E}-04$ & $(0.207,0.208)$ \\
\hline After May 1st & 0.13 & $1.85 \mathrm{E}-04$ & $(0.129,0.130)$ & 0.098 & $1.63 \mathrm{E}-04$ & $(0.098,0.099)$ \\
\hline \multicolumn{7}{|l|}{$\begin{array}{l}\text { Interaction between period and proportion } \\
\text { of Bachelor's degree holders }\end{array}$} \\
\hline April 1st-30th $*$ prop. frontline workers & -0.165 & $5.86 \mathrm{E}-04$ & $(-0.166,-0.164)$ & -0.184 & $5.38 \mathrm{E}-04$ & $(-0.185,-0.183)$ \\
\hline After May 1 st $*$ prop. frontline workers & -0.085 & $3.48 \mathrm{E}-04$ & $(-0.086,-0.084)$ & -0.092 & $3.19 \mathrm{E}-04$ & $(-0.093,-0.091)$ \\
\hline Intercept & 0.241 & $1.24 \mathrm{E}-04$ & $(0.240,0.241)$ & 0.237 & $1.11 \mathrm{E}-04$ & $(0.237,0.237)$ \\
\hline
\end{tabular}

Note: All p-values are smaller than 0.001. 
Appendix Table A3. Physical Distancing and the Proportion of Bachelor's Degree Holders, by Region

\begin{tabular}{|c|c|c|c|c|c|c|}
\hline \multirow[b]{2}{*}{ Variable } & \multicolumn{3}{|c|}{ Midwest $(\mathrm{N}=18,903,105$, Adj R-squared=0.22) } & \multicolumn{3}{|c|}{ South $(N=26,926,567$, Adj R-squared= 0.19) } \\
\hline & Coefficient & SE & $95 \% \mathrm{CI}$ & Coefficient & $\mathrm{SE}$ & $95 \% \mathrm{CI}$ \\
\hline \multicolumn{7}{|l|}{ Days from January 1 st } \\
\hline Linear term & $-2.33 \mathrm{E}-04$ & $1.42 \mathrm{E}-06$ & $(-2.36 \mathrm{E}-04,-2.31 \mathrm{E}-04)$ & $1.29 \mathrm{E}-04$ & $1.16 \mathrm{E}-06$ & $(1.27 \mathrm{E}-04,1.31 \mathrm{E}-04)$ \\
\hline Quadratic term & 2.17E-07 & $3.02 \mathrm{E}-09$ & $(2.11 \mathrm{E}-07,2.23 \mathrm{E}-07)$ & $-6.52 \mathrm{E}-07$ & 2.48E-09 & $(-6.57 \mathrm{E}-07,-6.47 \mathrm{E}-07)$ \\
\hline Proportion of Bachelor's degree holders & -0.064 & $1.90 \mathrm{E}-04$ & $(-0.064,-0.063)$ & -0.032 & $1.48 \mathrm{E}-04$ & $(-0.032,-0.032)$ \\
\hline \multicolumn{7}{|l|}{ Period $($ Reference $=$ Before April 1st $)$} \\
\hline April 1st-30th & 0.098 & $1.38 \mathrm{E}-04$ & $(0.097,0.098)$ & 0.072 & $1.09 \mathrm{E}-04$ & $(0.072,0.072)$ \\
\hline After May 1st & 0.031 & $1.32 \mathrm{E}-04$ & $(0.031,0.032)$ & 0.024 & $1.07 \mathrm{E}-04$ & $(0.024,0.025)$ \\
\hline \multicolumn{7}{|l|}{$\begin{array}{l}\text { Interaction between period and proportion } \\
\text { of Bachelor's degree holders }\end{array}$} \\
\hline April 1st-30th * prop. Bachelor's degree & 0.2 & $3.72 \mathrm{E}-04$ & $(0.199,0.201)$ & 0.201 & $2.90 \mathrm{E}-04$ & $(0.200,0.201)$ \\
\hline After May 1 st $*$ prop. Bachelor's degree & 0.099 & $2.21 \mathrm{E}-04$ & $(0.098,0.099)$ & 0.08 & $1.72 \mathrm{E}-04$ & $(0.080,0.081)$ \\
\hline \multirow[t]{3}{*}{ Intercept } & 0.29 & $8.24 \mathrm{E}-05$ & $(0.289,0.290)$ & 0.252 & $6.61 \mathrm{E}-05$ & $(0.252,0.252)$ \\
\hline & \multicolumn{3}{|c|}{ Northeast $(\mathrm{N}=15,037,277$, Adj R-squared $=0.28)$} & \multicolumn{3}{|c|}{ West $(\mathrm{N}=16,736,238$, Adj R-squared=0.22) } \\
\hline & Coefficient & SE & $95 \% \mathrm{CI}$ & Coefficient & SE & $95 \% \mathrm{CI}$ \\
\hline \multicolumn{7}{|l|}{ Days from January 1st } \\
\hline Linear term & $-2.30 \mathrm{E}-04$ & $1.83 \mathrm{E}-06$ & $(-2.33 \mathrm{E}-04,-2.26 \mathrm{E}-04)$ & $2.22 \mathrm{E}-04$ & $1.56 \mathrm{E}-06$ & (2.19E-04,2.25E-04) \\
\hline Quadratic term & $-1.80 \mathrm{E}-08$ & 3.89E-09 & $(-2.56 \mathrm{E}-08,-1.04 \mathrm{E}-08)$ & $-8.87 \mathrm{E}-07$ & 3.32E-09 & $(-8.93 \mathrm{E}-07,-8.80 \mathrm{E}-07)$ \\
\hline Proportion of Bachelor's degree holders & -0.104 & $2.22 \mathrm{E}-04$ & $(-0.105,-0.104)$ & -0.074 & $1.92 \mathrm{E}-04$ & $(-0.074,-0.074)$ \\
\hline \multicolumn{7}{|l|}{ Period $($ Reference $=$ Before April 1st $)$} \\
\hline April 1st-30th & 0.156 & $1.93 \mathrm{E}-04$ & $(0.156,0.156)$ & 0.092 & $1.58 \mathrm{E}-04$ & $(0.092,0.093)$ \\
\hline After May 1st & 0.071 & $1.76 \mathrm{E}-04$ & $(0.070,0.071)$ & 0.038 & $1.48 \mathrm{E}-04$ & $(0.037,0.038)$ \\
\hline \multicolumn{7}{|l|}{$\begin{array}{l}\text { Interaction between period and proportion } \\
\text { of Bachelor's degree holders }\end{array}$} \\
\hline April 1st-30th * prop. Bachelor's degree & 0.151 & 4.34E-04 & $(0.150,0.151)$ & 0.181 & $3.76 \mathrm{E}-04$ & $(0.180,0.182)$ \\
\hline After May 1st * prop. Bachelor's degree & 0.093 & $2.57 \mathrm{E}-04$ & $(0.092,0.093)$ & 0.101 & $2.23 \mathrm{E}-04$ & $(0.100,0.101)$ \\
\hline Intercept & 0.322 & $1.13 \mathrm{E}-04$ & $(0.321,0.322)$ & 0.289 & $9.36 \mathrm{E}-05$ & $(0.288,0.289)$ \\
\hline
\end{tabular}

Note: All p-values are smaller than 0.001. 
Appendix Table A4. Physical Distancing and Median Household Income, by Region

\begin{tabular}{|c|c|c|c|c|c|c|}
\hline \multirow[b]{2}{*}{ Variable } & \multicolumn{3}{|c|}{ Midwest $(\mathrm{N}=18,500,754$, Adj R-squared $=0.20)$} & \multicolumn{3}{|c|}{ South $(N=26,050,176$, Adj R-squared $=0.19)$} \\
\hline & Coefficient & SE & $95 \% \mathrm{CI}$ & Coefficient & $\mathrm{SE}$ & $95 \% \mathrm{CI}$ \\
\hline \multicolumn{7}{|l|}{ Days from January 1 st } \\
\hline Linear term & $-2.33 \mathrm{E}-04$ & $1.42 \mathrm{E}-06$ & $(-2.36 \mathrm{E}-04,-2.30 \mathrm{E}-04)$ & $1.34 \mathrm{E}-04$ & $1.18 \mathrm{E}-06$ & $(1.31 \mathrm{E}-04,1.36 \mathrm{E}-04)$ \\
\hline Quadratic term & $2.17 \mathrm{E}-07$ & $3.03 \mathrm{E}-09$ & $(2.11 \mathrm{E}-07,2.23 \mathrm{E}-07)$ & $-6.62 \mathrm{E}-07$ & 2.51E-09 & $(-6.67 \mathrm{E}-07,-6.57 \mathrm{E}-07)$ \\
\hline Income & $-5.62 \mathrm{E}-04$ & $1.24 \mathrm{E}-09$ & $(-5.64 \mathrm{E}-07,-5.59 \mathrm{E}-07)$ & $1.90 \mathrm{E}-04$ & $5.28 \mathrm{E}-10$ & $(1.89 \mathrm{E}-07,1.91 \mathrm{E}-07)$ \\
\hline \multicolumn{7}{|c|}{ Period $($ Reference $=$ Before April 1st $)$} \\
\hline April 1st-30th & 0.069 & $1.75 \mathrm{E}-04$ & $(0.069,0.070)$ & -0.019 & $1.16 \mathrm{E}-04$ & $(-0.020,-0.019)$ \\
\hline After May 1st & 0.029 & $1.47 \mathrm{E}-04$ & $(0.029,0.029)$ & 0.031 & $1.18 \mathrm{E}-04$ & $(0.031,0.031)$ \\
\hline \multicolumn{7}{|c|}{ Interaction between period and income } \\
\hline April 1st-30th $*$ income & $1.38 \mathrm{E}-03$ & 2.43E-09 & $(1.37 \mathrm{E}-06,1.38 \mathrm{E}-06)$ & $-4.48 \mathrm{E}-04$ & $1.04 \mathrm{E}-09$ & $(-4.50 \mathrm{E}-07,-4.46 \mathrm{E}-07)$ \\
\hline After May 1 st $*$ income & 4.78E-04 & $1.44 \mathrm{E}-09$ & $(4.75 \mathrm{E}-07,4.81 \mathrm{E}-07)$ & 8.39E-04 & $1.59 \mathrm{E}-09$ & $(8.35 \mathrm{E}-07,8.42 \mathrm{E}-07)$ \\
\hline \multirow[t]{3}{*}{ Intercept } & 0.306 & $9.93 \mathrm{E}-05$ & $(0.306,0.307)$ & 0.278 & $1.38 \mathrm{E}-04$ & $(0.278,0.278)$ \\
\hline & \multicolumn{3}{|c|}{ Northeast $(\mathrm{N}=14,523,150$, Adj $\mathrm{R}$-squared $=0.27)$} & \multicolumn{3}{|c|}{ West $(\mathrm{N}=16,349,784$, Adj R-squared $=0.23)$} \\
\hline & Coefficient & SE & $95 \% \mathrm{CI}$ & Coefficient & SE & $95 \% \mathrm{CI}$ \\
\hline \multicolumn{7}{|l|}{ Days from January 1 st } \\
\hline Linear term & $-2.31 \mathrm{E}-04$ & $1.83 \mathrm{E}-06$ & $(-2.35 \mathrm{E}-04,-2.28 \mathrm{E}-04)$ & $2.25 \mathrm{E}-04$ & $1.57 \mathrm{E}-06$ & $(2.22 \mathrm{E}-04,2.28 \mathrm{E}-04)$ \\
\hline Quadratic term & $-8.18 \mathrm{E}-09$ & 3.91E-09 & $(-1.58 \mathrm{E}-08,-5.18 \mathrm{E}-10)$ & $-8.92 \mathrm{E}-07$ & 3.34E-09 & $(-8.99 \mathrm{E}-07,-8.86 \mathrm{E}-07)$ \\
\hline Income & $-6.29 \mathrm{E}-04$ & 1.17E-09 & $(-6.31 \mathrm{E}-07,-6.26 \mathrm{E}-07)$ & $1.01 \mathrm{E}-04$ & $6.26 \mathrm{E}-10$ & $(1.00 \mathrm{E}-07,1.03 \mathrm{E}-07)$ \\
\hline \multicolumn{7}{|c|}{ Period $($ Reference $=$ Before April 1st $)$} \\
\hline April 1st-30th & 0.135 & $2.11 \mathrm{E}-04$ & $(0.134,0.135)$ & -0.029 & $1.59 \mathrm{E}-04$ & $(-0.029,-0.028)$ \\
\hline After May 1st & 0.072 & $1.84 \mathrm{E}-04$ & $(0.072,0.073)$ & 0.037 & $1.68 \mathrm{E}-04$ & $(0.037,0.037)$ \\
\hline \multicolumn{7}{|c|}{ Interaction between period and income } \\
\hline April 1st-30th $*$ income & 9.89E-04 & 2.28E-09 & $(9.84 \mathrm{E}-07,9.93 \mathrm{E}-07)$ & $-5.59 \mathrm{E}-04$ & $1.23 \mathrm{E}-09$ & $(-5.61 \mathrm{E}-07,-5.57 \mathrm{E}-07)$ \\
\hline After May 1 st $*$ income & 3.99E-04 & $1.35 \mathrm{E}-09$ & $(3.97 \mathrm{E}-07,4.02 \mathrm{E}-07)$ & $5.99 \mathrm{E}-04$ & $1.89 \mathrm{E}-09$ & $(5.95 \mathrm{E}-07,6.03 \mathrm{E}-07)$ \\
\hline Intercept & 0.333 & $1.21 \mathrm{E}-04$ & $(0.332,0.333)$ & 0.327 & $1.85 \mathrm{E}-04$ & $(0.327,0.328)$ \\
\hline
\end{tabular}

Note: All p-values are smaller than 0.001. Median household income is in thousands of dollars. 
Midwest $(\mathrm{N}=18,903,651$, Adj R-squared=0.18)

Variable

Days from January 1st

$$
\text { Linear term }
$$

Quadratic term

Prop. of residents over the age of 65

Period $($ Reference $=$ Before April 1st $)$

$$
\begin{aligned}
& \text { April 1st-30th } \\
& \text { After May 1st }
\end{aligned}
$$

\section{Coefficient}

$\mathrm{SE}$

$95 \% \mathrm{CI}$

$\begin{array}{ll}0.150 & 1.68 \mathrm{E}-04 \\ 0.063 & 1.44 \mathrm{E}-04\end{array}$

$(.150, .150)$

$(.063, .063)$

$\begin{array}{ccc}-2.33 \mathrm{E}-04 & 1.43 \mathrm{E}-06 & (-2.36 \mathrm{E}-04,-2.31 \mathrm{E}-04) \\ 2.16 \mathrm{E}-07 & 3.04 \mathrm{E}-09 & (2.10 \mathrm{E}-07,2.22 \mathrm{E}-07) \\ -0.024 & 4.20 \mathrm{E}-04 & (-0.024,-0.023)\end{array}$

Interaction between period and prop. residents over 65

April 1st-30th * prop. residents over 65

After May $1 \mathrm{st} *$ prop. residents over 65

0.012

$-0.026$

8.22E-04

0.276

4.87E-04

9.59E-05

$(0.011,0.014)$
$(-0.027,-0.025)$
$(0.276,0.276)$

South $(\mathrm{N}=26,926,487$, Adj R-squared=0.16)

Coefficient SE $95 \% \mathrm{CI}$

$\begin{array}{ccc}1.29 \mathrm{E}-04 & 1.18 \mathrm{E}-06 & (1.27 \mathrm{E}-04,1.31 \mathrm{E}-04) \\ -6.52 \mathrm{E}-07 & 2.51 \mathrm{E}-09 & (-6.57 \mathrm{E}-07,-6.47 \mathrm{E}-07) \\ 0.016 & 2.77 \mathrm{E}-04 & (0.016,0.017) \\ & & \\ 0.132 & 1.21 \mathrm{E}-04 & (0.131,0.132) \\ 0.054 & 1.12 \mathrm{E}-04 & (0.053,0.054) \\ & & \\ -0.032 & 5.42 \mathrm{E}-04 & (-0.033,-0.031) \\ -0.043 & 3.21 \mathrm{E}-04 & (-0.043,-0.042) \\ 0.240 & 7.15 \mathrm{E}-05 & (0.240,0.241)\end{array}$

West $(\mathrm{N}=16,736,710$, Adj R-squared=0 0.21)

Northeast $(\mathrm{N}=15,038,243$, Adj R-squared $=0.25)$

Coefficient

SE

$95 \% \mathrm{CI}$

Coefficient

SE

$95 \% \mathrm{CI}$

Days from January 1st

\section{Linear term \\ Quadratic term}

Prop. of residents over the age of 65

Period $($ Reference $=$ Before April 1st $)$

$\begin{array}{lll}\text { April 1st-30th } & 0.212 & 2.07 \mathrm{E}-04 \\ \text { After May 1st } & 0.111 & 1.82 \mathrm{E}-04\end{array}$

$-2.30 \mathrm{E}-04$

$-1.91 \mathrm{E}-08$

1.83E-06

3.91E-09

$-0.045 \quad 4.94 \mathrm{E}-04$
$(-2.33 \mathrm{E}-04,-2.26 \mathrm{E}-04)$

$(-2.67 \mathrm{E}-08,-1.14 \mathrm{E}-08)$

Interaction between period and prop. residents over 65

April 1st-30th * prop. residents over 65

\begin{abstract}
$-0.018$
\end{abstract}
9.66E-04

$-0.042$

0.293

Intercept
$5.73 \mathrm{E}-04$

1.19E-04
$(-0.046,-0.044)$

$(0.211,0.212)$

$(0.110,0.111)$

2.22E-04 1.57E-06

$-8.87 \mathrm{E}-07 \quad 3.36 \mathrm{E}-09$

$0.030 \quad 3.66 \mathrm{E}-04$

$0.155 \quad 1.55 \mathrm{E}-04$

$0.073 \quad 1.48 \mathrm{E}-04$

$(-0.020,-0.016)$

$(-0.043,-0.041)$

$(0.293,0.293)$
$-0.027 \quad 7.16 \mathrm{E}-04$

$-0.017 \quad 4.24 \mathrm{E}-04$

$0.260 \quad 9.26 \mathrm{E}-05$
(2.19E-04, 2.25E-04)

(-8.94E-07, -8.80E-07)

$(0.029,0.031)$

$(0.154,0.155)$

$(0.072,0.073)$

Note: All p-values are smaller than 0.001 . 